2013

\title{
National Football League General Managers: An Analysis of the Responsibilities, Qualifications, and Characteristics
}

Christopher R. Deubert

Glenn M. Wong

Daniel Hatman

Follow this and additional works at: https://digitalcommons.law.villanova.edu/mslj

Part of the Entertainment, Arts, and Sports Law Commons

\section{Recommended Citation}

Christopher R. Deubert, Glenn M. Wong \& Daniel Hatman, National Football League General Managers: An Analysis of the Responsibilities, Qualifications, and Characteristics, 20 Jeffrey S. Moorad Sports L.J. 427 (2013).

Available at: https://digitalcommons.law.villanova.edu/mslj/vol20/iss2/5

This Article is brought to you for free and open access by Villanova University Charles Widger School of Law Digital Repository. It has been accepted for inclusion in Jeffrey S. Moorad Sports Law Journal by an authorized editor of Villanova University Charles Widger School of Law Digital Repository. 


\title{
NATIONAL FOOTBALL LEAGUE GENERAL MANAGERS: AN ANALYSIS OF THE RESPONSIBILITIES, QUALIFICATIONS, AND CHARACTERISTICS
}

\author{
Christopher R. Deubert ${ }^{1}$, Glenn M. Wong ${ }^{2}$, And \\ DANiEl Hatman ${ }^{3}$
}

\section{INTRODUCTION}

One of the most desirable jobs in all of sports is undoubtedly that of General Manager (GM). A GM is generally responsible for the overall control and direction of the organization, including, perhaps most importantly, the success of the team on the field, court or rink. Perhaps the keen interest in being a GM is best exemplified through fantasy sports. Fantasy sports enable the fantasy team's owner to control an organization and select its players in the hopes of winning a championship. The Fantasy Sports Trade Association places the number of fantasy sports participants around 35 million Americans. ${ }^{4}$ Research has also shown a positive correlation between players starting in football fantasy leagues for a particular week and the television rating for those games. ${ }^{5}$ This correlation indicates that fans actively track "their" players and are vested in their results. The fan, in this case, is afforded the opportunity to conduct themselves like a GM: to select players, build a roster and see the outcomes in real time. With an ever growing pool of people

1. Associate, Peter R. Ginsberg Law, LLC, New York, NY; J.D./M.B.A., Fordham University School of Law and Graduate School of Business, New York, NY; B.S., Sport Management, University of Massachusetts, Amherst, MA. The authors would like to thank Kate Mullaney, M.B.A./M.S., Sport Management, University of Massachusetts, Amherst, MA, for her assistance with this article.

2. Professor, Department of Sport Management, Isenberg School of Management, University of Massachusetts, Amherst, MA; J.D., Boston College Law School; B.A. Brandeis University. Professor Wong is the author of ESSENTIALS OF SPORTS LAW (4th ed. 2010) and THE COMPREHENSIVE GUIDE TO CAREERS IN SPORTS (2nd ed. 2012).

3. Pro Scout, Philadelphia Eagles, Philadelphia, PA; M.B.A./M.S., Sport Management, University of Massachusetts, Amherst, MA; B.A., Psychology, State University of New York at Albany, Albany, NY.

4. See Fantasy Sports Trade Association, http://fsta.org/ (last visited Feb. 20, 2013) (stating market size at over 35 million adults).

5. See John A. Fortunato, The Relationship of Fantasy Football Participation with NFL Television Ratings, 3 Journal of Sport Administration \& Supervision 74, 7490 (2011), available at http://quod.lib.umich.edu/j/jsas/6776111.0003.114?rgn= main;view=fulltext (listing viewership for certain games and active players). 
who seek to turn this fantasy into reality, who has the requisite education, experience, and skills to make their dreams come true?

Longtime National Football League (NFL) writer Pat Kirwan aptly summarized the difficulties of the GM position:

Running an NFL franchise isn't easy. Can you evaluate personnel, manage a salary cap, negotiate contracts, select a head coach, handle the media, make tough decisions, cooperate with an owner, deal with the league office and, most importantly, carry out a vision for a winning franchise? If so, then you qualify for the job. ${ }^{6}$

Owners of NFL Clubs deciding on whom they want to lead their Club must ask themselves some difficult questions: What type of leader do I want? An experienced personnel man that comes in with a proven plan? A younger coach or scout with less experience but new and fresh ideas? Someone closer to the age of the owner who can relate to the boss? Someone who can recruit the best coach possible? A man who really knows the talent floating around the country in the draft and on the free agent market? How about a guy with a business-savvy approach?

This article builds upon research done in our two prior articles. In the article Major League Baseball General Managers: An Analysis of Their Responsibilities, Qualifications and Characteristics, we discussed the role of Major League Baseball (MLB) GMs, while examining the evolving paths people have taken to obtain the GM position. ${ }^{7}$ In MLB, there has been a clear trend emphasizing younger, highly educated people with a statistical analysis approach, while placing less emphasis on playing or coaching experience. ${ }^{8}$ Similarly, in the article National Basketball Association General Managers: An Analysis of the Responsibilities, Qualifications, and Characteristics, we discussed the role of a National Basketball Association (NBA) GM and examined the evolving paths people have taken to

6. See Pat Kirwan, Need a GM, Here's a short list of the best candidates, NFL.COM (Dec. 24, 2008), http://www.nfl.com/news/story/09000d5d80d9b253/article/ need-a-gm-heres-a-short-list-of-the-best-candidates.

7. Glenn M. Wong \& Chris Deubert, Major League Baseball General Managers: An Analysis of Their Responsibilities, Qualifications and Characteristics, 18 NINE: J. BASEBall Hist. \& Culture 74 (2010) (reviewing and analyzing General Manager position in MLB).

8. See id. at 117-21 (discussing decline of playing and coaching experience of MLB GMs and trend toward younger, highly educated individuals). 
obtain the position. ${ }^{9}$ This article will discuss the many duties of an NFL GM while also discussing the qualifications and characteristics that led them to the position. Not all NFL Clubs actually employ a person entitled "GM." Additionally, in some Clubs, the GM does not have final say in player personnel decisions. This article focuses on those individuals with final say entering the 2012 NFL season.

\section{The Duties of AN NFL GM10}

The broad scope of an NFL GM's professional responsibilities can be evidenced by the magnitude of NFL operations. The NFL and its thirty-two Member Clubs produced estimated revenues of $\$ 9.3$ billion in 2011 , or an average of nearly $\$ 300$ million per team. ${ }^{11}$ The clubs share approximately 60 percent of these revenues equally amongst the thirty-two clubs. ${ }^{12}$ Individual clubs range in estimated value from $\$ 2.1$ billion (Dallas Cowboys) to $\$ 770$ million (Jacksonville Jaguars). ${ }^{13}$ While these figures are not those of Fortune 500 companies, ${ }^{14}$ NFL GMs are clearly responsible for managing high stakes organizations and must make decisions on a daily basis that greatly impact the organization both on and off the field.

Depending on the organizational structure, a GM may have decision-making authority or advisory input in all or most aspects of the Club. The job description will certainly include football operations such as coach and staff selection, management of scouting departments, contract negotiations and most importantly, player

9. See Glenn M. Wong \& Chris Deubert, National Basketball Association General Managers: An Analysis of the Responsibilities, Qualifications and Characteristics, 18 VILL. SPORTS \& ENT. L.J. 213 (2011).

10. For purposes of this article, the term GM will focus on the person in the front office who has "final say" in football operations and player personnel matters. This could be an owner, as in the case of Mike Brown with the Cincinnati Bengals or Jerry Jones with the Dallas Cowboys, or it could also be a coach, like Bill Belichick of the New England Patriots.

11. See Sports Industry Overview, Plunkett research, http://www.plunkettresearch.com/sports-recreation-leisure-market-research/industry-statistics (last visited Feb. 20, 2013) (listing estimates following 2011 season).

12. See Bruce Garrioch, NHL CBA Negotiations Set to be Front Page News, ОтTAwA Sun, (Aug. 11, 2012), http://www.ottawasun.com/2012/08/11/nhl-negotiations-set-to-be-front-page-news (stating NFL clubs share more than 60 percent of revenue).

13. See Mike Ozanian, Cowboys Most Valuable NFL Team, FORBES (Sept. 5, 2012), http://www.forbes.com/nfl-valuations/ (valuing Cowboys at $\$ 2.1$ billion).

14. See Fortune 500, CNNMoney (May 21, 2012) http://money.cnn.com/ magazines/fortune/fortune500/2012/full_list/401_500.html (noting 500th company listed on Fortune 500, Molina Healthcare, earned revenues of approximately $\$ 4.7$ billion in 2011, more than half of revenues of all NFL Clubs combined). 
personnel decisions. It may also include business operational items such as finance, marketing, stadium development, media and community relations. As the business of the NFL has grown, so too have the legal, financial, and operational complications therein. NFL front offices have consequently grown to cover these many areas. GMs now not only oversee a large, complex network of individuals working in a variety of fields, but must themselves be experts or near experts in those fields.

\section{A. Salary Cap Management}

Many of a GM's duties must be analyzed within the confines of the NFL-National Football League Players Association (NFLPA) collective bargaining agreement (CBA). Pursuant to the National Labor Relations Act, employers and employees are obligated to negotiate in good faith over the terms and conditions of employment. ${ }^{15}$ Certain subjects, such as the rate and method of pay, discipline, safety and grievance and arbitration procedures, are mandatory subjects of bargaining, while others are merely permissive, such as the identity of the bargaining agent, status of supervisors and internal union or company affairs. ${ }^{16}$ The end result is a complex CBA that controls the terms and conditions of employment for NFL players and affects nearly every facet of NFL business. The most recent NFL-NFLPA CBA was executed in 2011 (2011 CBA) after considerable strife and litigation. ${ }^{17}$ Understanding the CBA is essential to a NFL GM's job duties.

\section{See 29 U.S.C. $§ 158(d)$ (2012).}

16. See Glenn Wong, Essentials of Sports Law 527 (ABC-CliO, 4th ed. 2010) (discussing mandatory and permissive subjects of bargaining).

17. See Chris Deubert, Glenn M. Wong \& John Howe, All Four Quarters: A Retrospective and Analysis of the 2011 Collective Bargaining Process and Agreement in the National Football League, 19 UCLA ENT. L. REv. 1 (2012). The National Football League Players Association decertified itself as the bargaining representative of NFL players on March 11, 2011, hours before the expiration of the collective bargaining agreement that the NFL and the NFLPA agreed to in 2006. See id. That night, nine current NFL players and one prospective NFL player, led by New England Patriots quarterback Tom Brady, filed an antitrust lawsuit against the NFL and its 32 Clubs. See Brady v. Nat'l Football League, 779 F. Supp. 2d 992 (D. Minn. 2011). In addition to the Brady lawsuit, the Players sought damages related to the NFL's television contracts that allegedly violated the 2006 CBA. See White v. Nat'l Football League, 766. F. Supp. 2d 941 (D. Minn. 2011). Retired players fought for their rights in the labor negotiations, and the NFL contended that the NFLPA had failed to bargain in good-faith in a proceeding before the National Labor Relations Board. See id. The NFL and NFLPA ultimately reached a settlement of the various lawsuits and agreed to a new CBA (the 2011 CBA) without missing any regular season games. See Deubert, supra note 17, at 5. 
Perhaps the most significant component of the CBA is the Salary Cap. The Salary Cap is "the absolute maximum amount of Salary that each Club may pay or be obligated to pay or provide to players . . . at any time during a particular League Year." 18 If only it were that simple. The legal basis for the Salary Cap and how the Salary Cap and Salary are determined are complicated issues that a GM must understand. While nearly every NFL Club employs a Director of Football Administration or similarly titled "cap guy," it is still essential that GMs understand the history of the Salary Cap, its present day machinations and how it affects the GM's ability to build a winning team.

\section{The Legal Basis for the Salary Cap}

The first salary cap in professional sports was instituted as part of the 1984 CBA between the NBA and National Basketball Players Association (NBPA). ${ }^{19}$ The concept of a salary cap is clearly intended to place a limit on the amount a sports team can spend on its players and consequently suppress the price of players' services (salaries) in the labor market. Such an agreement among thirtytwo competitors in a market would generally constitute a violation of the antitrust laws, which prohibit any contracts, combinations or conspiracies that unreasonably restrain trade. ${ }^{20}$

A salary cap is, however, exempt from the antitrust laws provided that it is negotiated and agreed to as part of a CBA. ${ }^{21}$ This policy is known as the non-statutory labor exemption. ${ }^{22}$ The $\mathrm{Su}$ preme Court of the United States has reasoned that "to give effect to federal labor laws and policies and to allow meaningful collective bargaining to take place, some restraints on competition imposed

18. See $2011 \mathrm{CBA}$, at art. 1 (quoting Collective Bargaining Agreement between NFL and NFLPA).

19. See NBA Salary Cap Info, InsideHoops, (July 10, 2012) www.insidehoops. com/nba-salary-cap.shtml (listing historical data regarding NBA salary cap).

20. See Sherman Antitrust Act, 15 U.S.C. $\$ 1$ (2004); see also Standard Oil Co. of New Jersey v. United States, 221 U.S. 1, 87 (1911) (ruling that only "unreasonable" restraints are illegal).

21. See Brady v. Nat'l Football League, 640 F.3d 785, 798 (8th Cir. 2011) (stating that " $[\mathrm{u}]$ nless the values of collective bargaining are implicated, federal labor laws yield to the regular antitrust framework") (citing Powell v. Nat'l Football League, 930 F.2d 1293, 1296 (8th Cir. 1989)).

22. See id. (explaining salary cap becomes non-statutory labor exemption from antitrust liability when NFLPA disclaims its role as Players' collective bargaining representative). 
through the bargaining process must be shielded from antitrust sanctions." 23

The scope of the non-statutory labor exemption has evolved over time. In 1972, Baltimore Colts' tight end John Mackey and thirty-five other NFL players brought a class action lawsuit against the NFL and its, at that time, twenty-six Member Clubs. ${ }^{24}$ The suit challenged the Rozelle Rule, named after then-NFL Commissioner Pete Rozelle. ${ }^{25}$ The Rozelle Rule permitted Commissioner Rozelle to determine the compensation, in the form of draft picks, players, or cash, to be paid to a Club who signs a player who most recently played for a different Club. ${ }^{26}$

The plaintiffs argued that the Rozelle Rule was an unreasonable restraint on trade under the antitrust laws because it deterred Clubs from signing free agents and suppressed player salaries. ${ }^{27}$ The NFL argued that the Rozelle Rule was implemented as part of the 1968 and 1970 CBAs and therefore immune from antitrust law by the non-statutory labor exemption. ${ }^{28}$

In 1975, the United States Court of Appeals for the Eighth Circuit ruled in favor of the plaintiffs and found that the Rozelle Rule was not protected by the non-statutory labor exemption. ${ }^{29}$ The Mackey case established an important three-prong test for determining when the non-statutory labor exemption applies:

23. Brown v. Pro Football, Inc., 518 U.S. 231, 236-37 (1996) (explaining difficulty employers and employees experience during collective bargaining due to lack of competition-restricting agreements needed to compromise).

24. See Mackey v. Nat'l Football League, 407 F. Supp. 1000, 1002 (D. Minn. 1975) (establishing that Amended Complaint was filed on October 11, 1972); see also Mackey v. Nat'l Football League, 543 F.2d 606, 609 n.2 (8th Cir. 1976) (establishing that suit was initiated by thirty-six players).

25. See Mackey, 543 F.2d at 609 (stating suit claimed Rozelle Rule violated Sherman Act and players sought to "enjoin[ ] its enforcement").

26. See id. at n.1 (explaining essentials of Rozelle Rule as providing Commissioner Rozelle with power to award compensation to teams that lost free agents in form of draft choices Commissioner Rozelle deemed fair and equitable).

27. See id. at 609 (stating plaintiffs asserted that "only employee groups are entitled to labor exemption" and defendants, employer group, should not be entitled to labor exemption for their unilateral action).

28. See id. at 612-13 (noting defendants claimed Rozelle Rule was "the subject of an agreement with the players union and that the proper accommodation of federal labor and antitrust policies requires that the agreement be deemed immune from antitrust liability.")

29. See Mackey, 543 F.2d at 623 (concluding that despite finding that non-labor parties "may potentially avail themselves of nonstatutory labor exemption . . . the exemption cannot be invoked here" because Rozelle Rule was not product of "bona fide arm's-length negotiations.") 
(1) The restraint on trade must primarily affect only the parties to the collective bargaining agreement;

(2) The issue must concern a mandatory subject of bargaining; and

(3) The issue must have been achieved through arm'slength bargaining. ${ }^{30}$

The Eighth Circuit determined that the NFL did not meet the third prong in Mackey. ${ }^{31}$ The court found that, even though the Rozelle Rule was included in the 1968 and 1970 CBAs, it served no benefit to NFL players (Players) and had not been accomplished through arm's length bargaining. ${ }^{32}$

The NFL and the Players negotiated new CBAs in 1977 and 1982 over various issues, notably a right of first refusal system in place of the Rozelle Rule, minimum salaries and benefits. ${ }^{33}$ The expiration of the 1982 CBA in 1987 marked a dramatic and litigious turning point in NFL labor relations that set the bounds of the nonstatutory labor exemption as it is known today.

The Players went on strike for 23 days during the 1987 season, during which time the NFL used replacement players. ${ }^{34}$ The Players decided to end the strike and instead filed a class action lawsuit challenging the right of first refusal / compensation system that had existed since the 1977 CBA in the Powell case. ${ }^{35}$

In Powell, the Players argued that the right of first refusal system violated section 1 of the Sherman Act because it unreasonably

30. See id. at 614 (listing certain principles court deduced from previous governing decisions regarding competing labor and antitrust interests).

31. See id. at 615-16 (noting Rozelle Rule "was unilaterally imposed by the NFL and member club defendants upon the players" and was not legitimately bargained over).

32. See id. (stating court could not find substantial evidence to support that both sides engaged in bona fide arm's-length bargaining over Rozelle Rule prior to 1968 and 1970 CBAs).

33. For more on the 1977 and 1982 CBA negotiations, see Chris Deubert, Glenn M. Wong and John Howe, All Four Quarters: A Retrospective and Analysis of the 2011 Collective Bargaining Process and Agreement in the National Football League, 19 UCLA Ent. L. Rev. 1 (2012).

34. See id. at 10-11. (explaining players' response to NFL using replacement players); Mike Tanier, And Now, a Season of Booth Reviews and Touchbacks, N.Y. Times, Sept. 4, 2011, at SP10, available at http://www.nytimes.com/2011/09/04/ sports/football/slower-lower-scoring-nfl-games-are-likely.html?_r=0 (noting impact replacement players had on statistics for 1987).

35. See generally Powell v. Nat'l Football League, 678 F. Supp. 777 (D. Minn. 1988) (explaining how non-statutory labor exemption protected teams from antitrust liability stemming from CBA provisions that restrained movement of players between teams). 
restrained player movement. ${ }^{36}$ The NFL moved for summary judgment, arguing that the system was protected by the non-statutory labor exemption. ${ }^{37}$ The Players responded by contending that the exemption was no longer applicable because the 1982 CBA had expired and impasse had been reached. ${ }^{38}$ Judge David Doty of the United States District Court for the District of Minnesota agreed with the NFL that the labor exemption survived expiration of the 1982 CBA because the terms and conditions of the 1982 CBA were still in effect. ${ }^{39}$ However, Judge Doty also ruled that the labor exemption would expire once an impasse was reached. ${ }^{40}$

The Eighth Circuit, in 1989, reversed Judge Doty's decision regarding when the labor exemption would expire. ${ }^{41}$ The Eighth Circuit ruled that the labor exemption would survive impasse and exist so long as there was an ongoing collective bargaining relationship. $^{42}$ In dissent, Judge Donald Lay recognized that the Players' only option to seek redress under the antitrust laws was to decertify the NFLPA as its bargaining representative. ${ }^{43}$

The Players voted to decertify the NFLPA shortly after the Eighth Circuit's decision in Powell. ${ }^{44}$ Several NFL players, led by the aptly named Freeman McNeil, then filed a lawsuit seeking an injunction against the NFL's proposed "Plan B" free agency system

36. See 15 U.S.C. $\$ 1$ (2004) (providing provisions of Sherman Antitrust Act that state " $[\mathrm{e}]$ very contract ... in restraint of trade or commerce among the several States . . . is declared to be illegal"); see Powell, 678 F. Supp. at 779 (stating players' complaint was based on NFL's continuous imposition of anti-competitive player restraints).

37. See id. at 778 (stating NFL moved for summary judgment declaring that "challenged restraints are insulated from antitrust scrutiny by operation of the nonstatutory labor exemption to the antitrust laws").

38. See id. at 781-82 (explaining that plaintiffs argued that because 1982 CBA expired, there is "no labor exemption from the antitrust laws shields the players").

39. See id. at 784 (stating that "a reasonably jury could not conclude that the player restraints contained in the 1982 collective bargaining agreement were not the product of bona fide arm's-length negotiations. Accordingly, summary judgment on this issue shall be entered in favor of defendants.").

40. See id. at 788 (ruling defendants' proposed standards would lead to illegal provisions being exempted from antitrust scrutiny and court could not adopt such rule).

41. Powell v. Nat'l Football League, 930 F.2d 1293, 1303-1304 (8th Cir. 1989) (explaining Eight Circuit's reversal regarding labor exemption expiration).

42. See id. at 1303 (explaining that labor exemption continue to apply during impasse if collective bargaining relationship continues).

43. See id. at 1309-10. (recognizing dissent's concern that Players' sole redress via antitrust required decertification of NLFPA as bargaining representative).

44. See Erick V. Posser, Brady v. NFL: How the Eighth Circuit "Saved" the 2011 NFL Season by Supporting Negotiation, Not Litigation, 19 Vill. Sports \& ENT. L.J. 603, 620 (2012) (reporting Players' decision to decertify NFLPA after Powell). 
and wage scale, alleging they violated the antitrust laws. ${ }^{45}$ The NFL had altered the right of first refusal / compensation system prior to the lawsuit in hopes it would be able to prove that the system was necessary for the survival of the league and was in its least restrictive form. ${ }^{46}$ Plan B free agency permitted Clubs to designate 36 players who would be subject to the right of first refusal/compensation system after each season. ${ }^{47}$ Undesignated players became unrestricted free agents. ${ }^{48}$

Judge Doty had already determined that the NFLPA had successfully relinquished its ability and right to bargain on behalf of NFL Players and that the labor exemption no longer applied as part of the Powell proceedings in 1991. ${ }^{49}$ The parties in McNeil crossmoved for summary judgment and Judge Doty ruled in the Players' favor in 1992, finding that if implemented, Plan B free agency and the wage scale would likely violate the antitrust laws. ${ }^{50}$

In 1992, following the McNeil decision, the Miami Dolphins' Keith Jackson and nine other players filed a lawsuit seeking injunctive relief preventing the implementation of the Plan B free agency system. ${ }^{51}$ Judge Doty granted the plaintiffs' request, finding that the outcome was likely to be the same based on the McNeil decision. 52

Riding the success of the McNeil and Jackson decisions, the Players filed a class action lawsuit in 1992 against the NFL seeking injunctive relief and antitrust damages for the NFL's Plan B free

45. See McNeil v. Nat'l Football League, 790 F. Supp. 871, 876 (D. Minn. 1992) (explaining suit filed by several Players alleging "Plan B" free agency plan against antitrust law).

46. See NFL Players Fight for Their Freedom: The History of Free Agency in the NFL, 9 Sports Law. J. 1, 27-29 (2002) (discussing strategy NFL used to prove Plan B free agency needed to preserve league).

47. See id. (describing nature of Plan B free agency).

48. See id. (continuing explanation of Plan B free agency).

49. See Powell v. Nat'l Football League, 764 F. Supp. 1351, 1358-59 (D. Minn. 1991) (describing District Court's holding NFLPA no longer represented Players and inapplicability of labor exemption).

50. See McNeil, 790 F. Supp. at 877 (explaining that summary judgment claims were filed and judge ruled in favor of Players and predicted Plan B would violate antitrust law). A trial on the merits of the plaintiffs' claims was held and the named plaintiffs were granted damages on their claims. The largest award was $\$ 240,000$ for San Diego Chargers' lineman Dave Richards. See McNeil v. Nat'l Football League, No. 90-476, 1992 WL 315292 (D. Minn. Sept. 10, 1992).

51. See Jackson v. Nat'l Football League, 802 F. Supp. 226, 228 (D. Minn. 1992) (identifying case by Dolphins player following McNeil decision and request for injunctive relief).

52. See id. at 230 (relaying that Judge granted Dolphins players' request for injunctive relief). 
agency system, the NFL Draft and the NFL Player Contract. ${ }^{53}$ The lead plaintiff in the lawsuit was the well-respected and future Hall of Fame defensive end Reggie White. White $v$. NFL presented NFL Clubs with the possibility of over a billion dollars in damages, after trebling, due to the restrictive policies it had imposed since the expiration of the $1982 \mathrm{CBA}$ in 1987.

On January 6, 1993, the parties reached a Stipulation and Settlement Agreement (SSA), approved by Judge Doty in August 1993, resolving the White case. ${ }^{54}$ The SSA included a $\$ 200$ million payout to the Players. ${ }^{55}$ The NFLPA recertified as the official bargaining representative of the Players as part of the SSA and the SSA became, in sum and substance, the new CBA between the NFL and Players (the 1993 CBA). ${ }^{56}$ Judge Doty retained jurisdiction over the SSA and CBA - an arrangement that would prove controversial in future years. ${ }^{57}$

The SSA was a monumental and long overdue resolution to years of litigation and labor strife. Furthermore, the 1993 CBA was a groundbreaking CBA that set the framework for every NFL CBA since. The Players gained the right to unrestricted free agency for the first time in exchange for the first ever Salary Cap in the NFL. ${ }^{58}$ Players could become unrestricted free agents after five years of experience and Clubs' payrolls were limited to a range of 62 percent to 64 percent of Defined Gross Revenue (DGR) (a mix of agreed upon League revenues), depending on the year. ${ }^{59}$

The Salary Cap's intended purpose is to create parity; a theoretical chance for each team to be successful by preventing the wealthier teams in the larger markets, e.g., the New York Giants, Dallas Cowboys and Chicago Bears, from buying up all the top tal-

53. See White v. Nat'l Football League, 822 F. Supp. 1389, 1395 (D. Minn. 1993) (identifying class action suit filed by Players for injunction and antitrust damages as result of Plan B system).

54. See id. at 1462-68 (explaining that Players and NFL reached settlement agreement).

55. See Will McDonough, Tentative Deal Reached in NFL; Free Agency Among Concessions Made by Owners to NFL Players, Boston Globe, Dec. 23, 1992, at 59 (identifying $\$ 200$ million payout included in settlement).

56. See Wong, supra note 16, at 496 (describing settlement agreement that reinstated NFLPA as Players bargaining agent and identifying settlement as basis for new CBA).

57. See White, 822 F. Supp. at 1414 (identifying retention of jurisdiction by Judge Doty).

58. See Wong, supra note 16, at 496 (discussing new CBA which included unrestricted free agency and salary cap).

59. See White, 822 F. Supp. at 1412-13 (identifying specifics of unrestricted free agency and salary cap). 
ent. This statement has proven to mostly be true, though dynasties still remain. ${ }^{60}$

Former NFL Commissioner Paul Tagliabue, in describing changes to the Salary Cap in the 2001 CBA, elaborated on the goals of the Salary Cap:

$[u]$ nder any system you're going to have a cyclical pattern of success and failure. The draft ultimately is going to produce such a pattern. This cap system will do the same. It's another governing mechanism. If you succeed, you can't keep an inordinate number of players. The up escalator is a lot faster than it was before. ${ }^{61}$

The Washington Redskins, a Club that had been to four Super Bowls in the decade prior to the Salary Cap, were also a target. Then Redskins GM Charley Casserly responded in kind: “[t]here's a salary cap coming, and our team has to be very aware of that. We knew our club would lose players. This is no surprise."62 Nevertheless, the Redskins have not returned to the Super Bowl and have only made the playoffs three times in the Salary Cap era.

\section{Determination of Salary}

The definition of Salary is fairly straightforward. "'Salary' means the compensation in money, property, investments, loans, or anything else of value to which an NFL player . . . is entitled in accordance with a Player Contract, but not including benefits."63 The forms of Salary and how they are calculated for Salary Cap purposes, however, is more complicated. While we briefly discuss the definitions, calculations and purposes of the various forms of Salary

60. See Larsen et al., The Impact of Free Agency and the Salary Cap on Competitive Balance in the National Football League, Journal of Sports Econ., Mar. 2009, Vol. 7, 374-90 (2006) (finding that "free agency and salary cap restrictions tend to promote competitive balance, whereas a concentration of player talent reduces competitiveness among teams"); see also Travis Lee, Competitive Balance in the National Football League after the 1993 Collective Bargaining Agreement, Journal of SpORTs ECON., Feb. 2010, Vol. 11, 77-88 (indicating that salary cap has been mostly successful in creating parity in league); see also Has the NFL Salary Cap Created Parity?, SPORTS Illustrated, www.fannation.com/blogs/post/109116 (last visited Mar. 22, 2013) (pointing out that despite increased parity from salary cap, dynasties remain).

61. Peter King, Game Plan, Sports Illustrated, Aug. 30, 1999, at 74 (noting former commissioner's belief regarding salary caps ability to create parity).

62. Glen Macnow, Phoenix gets Redskins Receiver Clark, PhiladelPhia InQuirer, March 23, 1993, at 1 (discussing reaction of Redskins' owner to salary cap).

63. NFL Collective Bargaining Agreement art. $13 \$ 4(\mathrm{a})$ (2011-2020) [hereinafter $2011 \mathrm{CBA}$ ] (providing definition of salary according to collective bargaining agreement) 
below, a more detailed explanation can be found in our prior law review article, Understanding the Evolution of Signing Bonuses and Guaranteed Money in the National Football League: Preparing for the 2011 Collective Bargaining Negotiations. ${ }^{64}$

NFL players are compensated in a variety of ways, including negotiated compensation, such as "Paragraph 5 Salary," signing bonuses, option bonuses, incentive clauses, roster bonuses, and workout bonuses, and non-negotiated compensation, such as playoff winnings and the Performance-Based Pool. Article 13 of the 2011 CBA describes how each should be accounted for Salary Cap purposes.

"Paragraph 5" salary refers to the base compensation paid to players according to Paragraph 5 of their NFL Player Contract. ${ }^{65}$ When the average fan thinks of NFL contracts not being guaranteed, he or she is thinking of Paragraph 5 salary. Paragraph 5 minimum salaries are based upon the amount of Credited Seasons a player has earned; for the 2012 NFL season, the minimum salary of a player with zero credited seasons was $\$ 390,000$, while for players with four to six credit seasons the minimum salary was $\$ 700,000 .{ }^{66}$

Signing bonuses are the most common form of guaranteed compensation, and the most important in terms of Salary Cap calculations. When a Club gives a player a signing bonus, it prorates, or amortizes, the bonus over the term of the contract for Salary Cap purposes, for a period not to exceed five years. ${ }^{67}$ For example, if a player signs a 5-year deal with a $\$ 10$ million signing bonus, the bonus is prorated at an annual value of $\$ 2$ million. The player's resulting Salary Cap charge for each season of the contract would be $\$ 2$ million, plus his Paragraph 5 Salary and any other bonuses or incentives for that season.

Option bonuses are lump-sum or scheduled payments paid upon exercise of the option by the Club. In consideration for the lump-sum payment, the player's contract with the Club is extended, typically for one season. For Salary Cap purposes, option bonuses

64. 16 UCLA ENT. L. Rev. 179 (2009).

65. See id. at art. 1 (explaining definition of salary received by players according to particular section of player contract).

66. See id. at art. 26 (providing numerical amounts of NFL minimum salary based on number of "credited seasons" player has attained). A "credited season" is earned when a player is on "full pay status for a total of three or more regular season games." See id. at $\S 2$ (describing credited season calculation).

67. See id. at art. 13, $\S 6(\mathrm{~b})$ (i) (explaining process by which signing bonuses are prorated). 
are treated as signing bonuses. ${ }^{68}$ As a result, when an option bonus is exercised, the bonus is prorated over the remaining years on the contract, up to a maximum of five years. Using the example from earlier (where a player signed a five-year deal with a \$10 million signing bonus), if a Club exercises an $\$ 8$ million option bonus after the player's second season for one additional season, the $\$ 8$ million bonus is prorated over the now four years remaining on the contract, increasing the Salary Cap charge for each of those years by $\$ 2$ million.

Incentives are a broad category of bonuses based on individual and Club performance with myriad Salary Cap treatment particulars, as will be discussed in more detail below.

Roster bonuses are lump-sum or scheduled payments paid when a player is on the team's roster on a specific date, often the fifth day of the League Year. ${ }^{69}$ Similarly, workout bonuses are lump-sum or scheduled payments paid when a player timely reports and participates in the requisite off-season workouts, weight lifting sessions, organized team activities or training camps at the team's training facility. Both roster bonuses and workout bonuses almost always count towards the Salary Cap in the full amount in the year in which they are paid.

The principal form of non-negotiated compensation that counts towards a Club's Salary Cap is the Performance-Based Pool. ${ }^{70}$ The Performance-Based Pool, which equaled \$3.46 million per Club in the 2012 League Year, is distributed to players at the end of each season using a formula that depends on their playing time, compensation and playing time relative to compensation. ${ }^{71}$ Essentially, a low paid player who ends up being an important player on the team can earn in excess of $\$ 200,000$, or nearly $50 \%$ of their base salary. ${ }^{72}$ Conversely, high paid players that do not perform well may receive only a few thousand dollars.

68. See id. at $\S 6(\mathrm{~b})$ (iii) (listing terms that "signing bonus" shall include when calculating proration).

69. See id. at art. 1 (defining a "League Year" as "the period from March [_] of one year through and including March [__ of the following year, or such other one year period to which the NFL and NFLPA may agree.")

70. See id. at art. 28, $§ 1$ (defining "performance-based pool" and its relation to team's salary cap).

71. See id. at $\S 3$ (mandating distribution of fund to player each league year).

72. See Chris Deubert \& Glenn M. Wong, Understanding the Evolution of Signing Bonuses and Guaranteed Money in the National Football League: Preparing for the 2011 Collective Bargaining Negotiations, 16 UCLA EnT. L. Rev. 179, 199 (2009) (explaining circumstance where low paid player receives large portion of fund at end of league year). 


\section{Determination of the Salary Cap}

Substantive changes to the Salary Cap occurred in the 2006 CBA. The 2006 CBA replaced the DGR definition with that of Total Revenue (TR). ${ }^{73}$ TR included certain increasingly important revenue sources not previously included in DGR. These sources included stadium revenues related to football such as concessions, parking, local advertising and promotion, signage, magazine advertising local sponsorship agreements, stadium clubs, and luxury box income-revenue sources explicitly excluded from DGR previously. ${ }^{74}$ Consequently, TR was significantly higher than DGR had been. In exchange, the Players only received approximately 57.5 percent of TR as opposed to a maximum of 65.5 percent of DGR under the earlier CBAs. ${ }^{75}$ Moreover, before the Players' share of TR was determined, the NFL deducted five percent for expenses and 1.8 percent for the NFL's G-3 Stadium Program. ${ }^{76}$ These expense deductions were estimated to be approximately $\$ 1$ billion per year. ${ }^{77}$ As a result, the Players actually received much closer to 50 percent of all revenues. ${ }^{78}$

Despite the changes in the calculations of the Salary Cap, the actual amounts received by the Players increased significantly in the $2006 \mathrm{CBA}$ as a result of the newly included revenue sources. ${ }^{79}$ The increase in player compensation would prove to be a crucial point of contention moving forward.

Leading into and during the 2011 CBA negotiations and resulting lockout it was often said that if the two sides could agree on how to divide the revenues, then the other issues would fall into place. ${ }^{80}$

73. See NFL Collective Bargaining Agreement art. I, §3(al) (2006-2012) [hereinafter $2006 \mathrm{CBA}$ ] (defining total revenue as "all of the League and Team revenues that are included within the definition of Total Revenues, as set forth in Article XXIV").

74. See Deubert \& Wong, supra note 72, at 181 (listing various revenue streams considered to be "total revenue").

75. See $2006 \mathrm{CBA}$, supra note 73, at art. XXIV $§ 4$ (a) (noting actual percentage received by players from new calculations).

76. See id. at $\S 1$ (a) (xiv) (providing definition of "Total Revenue").

77. See Mike Florio, Under Proposed Deal, Players Will Get 48 Percent of the Total Revenue, ProFootball Talk.com (June 22, 2011, 8:06 AM), http://profootballtalk. nbcsports.com/2011/06/22/under-proposed-deal-players-will-get-48-percent-ofthe-total-revenue/ (correcting misdirected belief that players receive larger share of revenue under new collective bargaining agreement's revenue model).

78. See id. (noting more realistic percentage received by players under new collective bargaining agreement).

79. See Deubert \& Wong, supra note 72, at 181 (describing increase in share received by players under 2006 agreement).

80. Mike Florio, With Trust Restored, Talks Turn to Issues Other Than Revenue Split, ProFootballTalk.com (June 23, 2011, 1:37 PM), http://profootballtalk.nbc 
The NFLPA undoubtedly wanted to ensure that its Players continued to receive their fair share of revenues that Commissioner Roger Goodell projected to grow by over $\$ 1$ billion per year to a goal of $\$ 25$ billion in 2027.81

During the 2011 CBA negotiations, the two sides were having difficulty determining how to divide up the increasingly diverse and significant revenue streams until a proposal from the NFL's Treasurer, Joe Siclare, was made. ${ }^{82}$ Siclare substantially proposed the revenue split to which the two sides agreed. The parties scuttled TR and now divide up All Revenue (AR), which includes all revenues "from all sources, whether known or unknown, derived from, relating to or arising out of the performance of players in NFL football games . . .."83 The Players and Clubs now divide three main "Revenue Buckets," with the Players receiving the following shares:

(a) 55 percent of League Media. ${ }^{84}$ League Media includes all broadcasting revenues, including television, satellite, radio and internet. ${ }^{85}$ These revenues were worth approximately $\$ 4$ billion in 2011.86

(b) 45 percent of NFL Ventures/Postseason. ${ }^{87}$ NFL Ventures/Post-season includes all revenues arising from the

sports.com/2011/06/23/with-trust-restored-talks-turn-to-isues-other-than-revenuesplit/ (labeling deal as "done" despite nothing being signed).

81. See Daniel Kaplan, SBJ: Goodell Sets Revenue Goal of $\$ 25$ billion by 2027 for NFL, SportingNews.com (Apr. 5, 2010, 7:51 PM), http://aol.sportingnews.com/ nfl/story/2010-04-05/sbj-goodell-sets-revenue-goal-25-billion-2027-for-nfl (conveying message that while $\$ 25$ billion may be "ambitious" it is unquestionably an indicator of NFL business expansion in recent years).

82. See Mike Florio, Joe Siclare Gets His Props for Propping Up Labor Deal, ProFootball Talk.com (July 29, 2011, 2:32 PM), http://profootballtalk.nbcsports. com/2011/07/29/joe-siclare-gets-his-props-for-propping-up-labor-deal/ (describing innovative idea that propelled talks between two sides during negotiations).

83. See 2011 CBA, supra note 63, at art. 12, § 1(a) (providing definition of "All Revenue").

84. See id. at art. $12 \S 6(\mathrm{a})-(\mathrm{a})(\mathrm{v})$ (noting subdivision of all revenue into three separate categories and definition of "league revenue"); see id. at $\S 6$ (c) (i) (describing calculation of "other league year cost amounts"); see also Dex McLuskey and Aaron Kuriloff, NFL Signs Nine-Year Extensions of Television Contracts With CBS, FOX, NBC, Bloomberg, (Dec. 15, 2011, 9:00PM), http://www.bloomberg.com/news/ 2011-12-14/nfl-renews-television-contracts-with-cbs-fox-nbc-networks-through-2022. html (describing media rights contracts signed by NFL for new collective bargaining agreement); see also $2011 \mathrm{CBA}$, supra note 19, at art. $12 \S 6$ (c)(i).

85. $I d$. at art. $12 \S 6(\mathrm{a})(\mathrm{i})$.

86. See Dex McLuskey and Aaron Kuriloff, NFl Signs Nine-Year Extensions of Television Contracts with CBS, FOX, NBC, Bloomberg (Dec. 15, 2011, 9:00 PM), http:// www.bloomberg.com/news/2011-12-14/nfl-renews-television-contracts-with-cbsfox-nbc-networks-through-2022.html (noting "NFL currently receives about $\$ 4$ billion a year in television rights fees from companies").

87. 2011 CBA, supra note 63 , art. $12 \S 6(\mathrm{c})(\mathrm{i})$. 
operation of postseason NFL games and all revenues arising from operating of NFL-affiliated entities, including NFL Ventures, NFL Network, NFL Properties, NFL Enterprises, NFL Productions, and NFL Digital Media Group. ${ }^{88}$ (c) Forty percent of local revenues. ${ }^{89}$ "Local revenues include those revenues not included in League Media AR or NFL Ventures/Postseason AR," and specifically include

88. See id. at art. $12 \S 6$ (a) (ii) (describing NFL Ventures/Postseason); see also Tommy Craggs, Exclusive: Leaked Documents Show Operating Profits for NFL Ventures Rose 29 Percent Last Year, DeAdsPin (July 15, 2011, 1:10 PM), http://deadspin.com/ 5821386/audited-financials-operating-profit-for-nfl-ventures-lp-rose-from-999-million-to-13-billion-last-year (describing NFL Ventures). NFL Ventures is responsible for negotiating all of the league's major sponsorship, marketing, and media rights deals. See id. NFL Ventures, which Commissioner Goodell ran before becoming Commissioner, includes four wholly-owned subsidiaries: NFL Enterprises, NFL Properties, NFL Productions, and NFL International. See id.; see also NFL Network, NFL.com (last visited Mar. 22, 2013), www.nfl.com/nflnetwork (describing NFL Network). NFL Network is the league-owned and operated television network devoted full-time to the NFL, including broadcasting select Thursday night games. Id; see also Am. Needle, Inc. v. Nat'l Football League, 130 S. Ct. 2201 (2010) (discussing NFL Properties and ensuing licensing litigation). NFL Properties is responsible for licensing, sponsorship, and marketing. See id. NFL Properties was the subject of Am. Needle, Inc. v. Nat'l Football League. See id. NFL Properties was created by the 32 individual Clubs to collectively market and license the Clubs' individual intellectual property, such as names, colors, logos, and trademarks. See $i d$. In 2000, the Clubs-through NFL Properties-granted Reebok an exclusive license to produce and sell trademarked headwear for the 32 Clubs. See id. American Needle-a former licensee and creator of NFL appareled headwear-could no longer create headwear with NFL logos and trademarks. See id. American Needle challenged the exclusive license as an illegal restraint of trade by the 32 NFL Clubs. See id. The Northern District of Illinois granted the NFL summary judgment after finding that NFL Properties constituted a single entity for antitrust purposes, and therefore there was no contract, combination, or conspiracy to restrain trade. See Am. Needle, Inc. v. New Orleans La. Saints, 496 F. Supp. 2d 941, 943 (N.D. Ill. 2007). The Seventh Circuit affirmed. See Am. Needle, Inc. v. Nat'l Football League, 538 F. 3d 736 (7th Cir. 2008). The Supreme Court reversed. See Am. Needle, 130 S. Ct. 2201. While the Court noted that NFL Clubs "depend upon a degree of cooperation for economic survival," the necessity of cooperation does not transform concerted action into the independent action of a single-entity. Id. at 2214. Furthermore, the Court noted that "even if league-wide agreements are necessary to produce football, it does not follow that concerted activity in marketing intellectual property is necessary to produce football." Id. at n.7; see also NFL Films, NFL FILMS, (last visited Mar. 22, 2013), www.nflfilms.com (describing NFL Productions). NFL Productions, also known as NFL Films, is the league-owned film company that for over fifty years has produced award-winning films about the NFL. See id.; see also NFL.COM Privacy Policy, NFL.COM. (March 30, 2011), http:// www.nfl.com/help/privacy (describing NFL Digital Media Group). NFL Digital is responsible for the league's technology and new media ventures, including www. nfl.com and NFL Mobile. See id.

89. See 2011 CBA, supra note 63, art. $12 \S 6$ (c)(i) (listing Players' shares of local revenues). 
revenues from the sale of preseason television broadcasts. ${ }^{90}$

It is important to point out that the amount the Players "receive" is actually called the Player Cost Amount, which includes the Players' benefits. ${ }^{91}$ In the 2011 League Year, the Player Cost Amount was pegged at $\$ 142.4$ million per Club, with $\$ 22.025$ million $(15 \%)$ of that amount allocated towards Player benefits. ${ }^{92}$ The Salary Cap was thus only $\$ 120.375$ million. ${ }^{93}$

The 2011 CBA reduced the acceptable range for the Players' share of revenues to a $1 \%$ band. The Players are limited to an upward band of $48 \%$ of AR for League Years 2012-2014 and 48.5\% from 2015-2020. ${ }^{94}$ At the same time, the Players' share of AR cannot be below $47 \% .95$

Under the 2006 CBA, the Players were effectively guaranteed 50 percent of TR, including both salary and benefits. ${ }^{96}$ The 2006 CBA also prohibited the Players' share of TR, including both salary and benefits, from exceeding 61.6 percent of TR. ${ }^{97}$ AR under the 2011 CBA will exceed TR under the 2006 CBA based on the absence of expense deductions. Consequently, the Players are receiving a more definite piece of a larger pie.

After AR is determined, each Club's individual Salary Cap must be calculated. This process did not change in the 2011 CBA. Each Club's Salary Cap is calculated by deducting Player benefits from the Players' share of revenues and then dividing by the number of Clubs in the NFL. ${ }^{98}$

The 2011 CBA has, however, made important changes to how much each Club must spend in actual cash. Under the 2006 CBA, Clubs were required to have a Team Salary of at least 84 percent of their Salary Cap, increasing 1.2 percent annually to a high of 87.6

90. See id. at art. $12 \S 6($ a) (iii) (describing local revenues).

91. See id. at art. $12 \S 6$ (b) (clarifying terminology relevant for Player salaries).

92. See id (explaining Player Cost Amount and Player benefits for 2011 League Year).

93. See id. at art. XII, §6(b) (noting salary cap).

94. See id. at art. $12 \S 6$ (c) (ii) (explaining band percentages).

95. See id (noting minimum band percentage).

96. See 2006 CBA, supra note 73, at art. XXIV, $\$ 3$ (discussing split of TR). The guarantee actually only kicked in when there was a salary cap in place; which there was in every League Year of the 2006 CBA except for 2010. See id.

97. See id. at art. XXIV, $\S 4$ (c) (determining player's share of TR).

98. Compare 2006 CBA, supra note 73, at art. XXIV $\S 4(a)$, with 2011 CBA, supra note 63, at art. 12, §6(c)(v) (discussing Salary Cap calculations). 
percent in 2009. ${ }^{99}$ However, the calculation of Team Salary is the same as that used for Salary Cap purposes, meaning it includes the prorated portions of signing and option bonuses paid in previous years. ${ }^{100}$ Consequently, Team Salary was always actually less than the actual cash paid by the Club for that League Year.

The 2011 CBA is not concerned with what a Club's Salary Cap total might be, but rather with the actual amount of cash that is being spent by the Clubs. The 2011 CBA requires that the Clubs, as a collective unit, spend 99 percent of the Salary Cap for the 2011 and 2012 League Years in cash (Guaranteed League-Wide Cash Spending). ${ }^{101}$ For each four-year period from 2013-16 and 2017-20, the Clubs must spend 95 percent of the Salary Cap in cash. ${ }^{102}$

The 2011 CBA technically does not impose a Salary "floor" for each Club as the 2006 CBA did. ${ }^{103}$ The 2011 CBA instead requires that Clubs spend at least 89 percent of the Salary Cap in cash for each four-year period from 2013-16 and 2017-20 ("Minimum Team Cash Spending"). ${ }^{104}$ The Players are not interested in how Clubs structure contracts and allocate salaries for Salary Cap purposes, but instead are concerned with ensuring that the Players actually receive a certain percentage of money. A Club that fails to reach the Minimum Team Cash Spending threshold must pay the shortfall to its players before the next season. ${ }^{105}$ There is no Minimum Team Cash Spending in the 2011 or 2012 League Years.

There are, of course, other nuances to the operation of the Salary Cap. The NFL Salary Cap is generally considered a "hard" cap, in that it largely cannot be exceeded. Other sports' salary caps or competitive balance measures vary considerably, including the NBA's "soft" salary cap, which permits clubs to exceed the salary cap

99. See 2006 CBA, supra note 73 , at art. XXIV, $§ 5$ (stating Team Salary must be $84 \%$ of their Salary Cap).

100. See id. art. I, §3(au) (determining calculation of Team Salary).

101. See 2011 CBA, supra note 63, at art. $12 \S 8$ (a) (discussing salary cap requirements).

102. See id. art. $12 \S 8$ (b) (stating that teams must spend $95 \%$ of their salary cap in cash during four-year periods).

103. See 2006 CBA, supra note 73, at art. XXIV § 5(a) ("Each Team shall be required to have a Team Salary of at least the Minimum Team Salary at the end of each Capped Year.").

104. See 2011 CBA, supra note 63 , at art. $12 \S 9$ (a) (abandoning yearly requirements of $2006 \mathrm{CBA})$.

105. See id. art. $12 \S 9$ (b) (requiring shortfall payment directly to players). 
with exceptions. ${ }^{106}$ The NFL Salary Cap does, however, permit for certain exceptions for veterans playing for the league minimum. ${ }^{107}$

Each Club's Salary Cap is also uniquely based upon whether certain incentives were earned by the Club's players in the previous season. ${ }^{108}$ The Club's Salary Cap can be raised or lowered depending on incentives deemed "likely to be earned" or "unlikely to be earned." 109 These incentives, outlined in Exhibits A, B and C, Article 13, section 6, permit a player's compensation to be tied to: (A) Team Incentives, e.g., Points Scored by Team, Points Allowed by Team, Wins, Super Bowl; (B) Individual Incentives, e.g., Touchdowns, Rushing Yards, Sacks; and (C) Honors and Recognized Media, e.g. Pro Bowl and NFL MVP. ${ }^{110}$ Many incentives are tied to team statistical performance; if the team met or exceeded the specified performance in the prior season, the incentive is deemed likely to be earned, whereas if the team did not meet the specified performance in the prior season, the incentive is deemed not likely to be earned. ${ }^{111}$

A likely to be earned bonus must be included as part of Team Salary in the current year's Salary Cap. ${ }^{112}$ If the bonus is subsequently not earned, the amount of the bonus is added to the Club's Salary Cap for the next season, provided the Club has not exceeded the Salary Cap. ${ }^{113}$ Conversely, if a not likely to be earned bonus is actually earned, the amount must be subtracted from the next year's Salary Cap. ${ }^{114}$

106. See Glenn M. Wong \& Chris Deubert, National Basketball Association General Managers: An Analysis of the Responsibilities, Qualifications and Characteristics, 18 VILL. SPORTs \& ENT. L.J. 213, 220 (2011) (discussing various exceptions to NBA salary cap).

107. See 2006 CBA, supra note 73, at art. XXXVIII-A (discussing NFL Salary Cap under 2006 CBA); see also 2011 CBA, supra note 63, at art. XXVII (discussing NFL Salary Cap under 2011 CBA).

108. See 2006 CBA, supra note 73, at art. XXIV § 7(c) (ii-iii); see also 2011 CBA, supra note 19 , art. XIII $\S 6$ (c) (ii-iii).

109. See 2011 CBA, supra note 63, at art. 13, §6(c) (i) ("Any incentive within the sole control of the player (e.g., non-guaranteed reporting bonuses, off-season workout and weight bonuses) shall be deemed 'likely to be earned.'”); see also 2011 CBA, supra note 63 , at art. 13, §6 (c) (ii-iii) (explaining incentives not likely to be earned).

110. See 2011 CBA, supra note 63, at 98-101 (outlining incentives available).

111. See 2011 CBA, supra note 63, at art. 13, §6(c) (iv) (stating how to identify performance likely to be earned).

112. See 2011 CBA, supra note 63 , at art. 13, § 6(c) (i) (requiring that likely to be earned incentives be included in team salary).

113. See 2011 CBA, supra note 63, at art. 13, §6(c)(iii) (stating procedures when performance bonuses previously included in salary are not met).

114. See 2011 CBA, supra note 63, at art. 13, §6(c) (ii) (stating procedures when performance bonuses not previously included in salary are met). 
The 2011 CBA provides Clubs with further flexibility by permitting Clubs to carry over Salary Cap room from one year to the next. ${ }^{115}$ The 2011 CBA does not limit the amount a Club may carry over. However, the carry-over amount will be practically limited by the requirement that each Club spend at least 89 percent of the Salary Cap in cash for each four-year period from 2013-2016 and 2017-2020. ${ }^{116}$ Nevertheless, Clubs may be more strategic in their spending plans and may target specific years for success by signing better players as a result of carried over Salary Cap room.

When and how to use the Salary Cap's flexibility can of course make or break a Club for several years. Atlanta Falcons President Rich McKay explained that "[i]f you decide to become one of those teams that is so-called 'excellent' at manipulating the cap, you are building yourself a window (to win) that gets smaller and smaller as you continue to manipulate .... But if you are disciplined about the cap . . . and make hard choices, I think you can keep winning." 117

Clearly, the Salary Cap is complicated and today's GMs have their work cut out for them in understanding it. As mentioned earlier, most GMs turn over nearly all Salary Cap duties to a Director of Football Administration, who often is a licensed attorney. These positions have become vital, as the Salary Cap ramifications of each personnel decision comes with considerable financial risk. Franchises can ill afford to make a mistake that causes long-term damage to their Salary Cap. Former New York Jets GM Terry Bradway elaborated on the importance of a capable Salary Cap manager: "I think if you're set up correctly and you've got the right people doing all those jobs and you can coordinate the salary-cap part of it with the player personnel part of it and the coaching part of it, then you've got a chance."118

Bradway's experience as a GM is a particularly good example of the importance of a good Salary Cap manager. Bradway was a long-time scouting and personnel expert with both the Jets and Kansas City Chiefs until he ascended to the Jets' GM position in

115. See 2011 CBA, supra note 63, at art. 13, § 6(b) (v) (stating how clubs may "carry over" salary room).

116. See 2011 CBA, supra note 63, at art. 12, § 9(a) (outlining minimum team cash spending)

117. See Kimberly Jones, Cap I\$ King, Newark Star Ledger, Jan. 30, 2005, at 1 (discussing salary cap strategies).

118. See Kimberly Jones, They are all in this together, Newark Star Ledger, Jan. 31,2005 , at 44 (emphasizing importance of salary cap strategy). 
2001. ${ }^{119}$ That same year, the Jets' promoted Mike Tannenbaum to Assistant General Manager. ${ }^{120}$ Tannenbaum was not an ex-football player or scout but instead received an accounting degree from the University of Massachusetts-Amherst and a law degree from Tulane University. ${ }^{121}$ Tannenbaum's considerable experience in handling the Salary Cap permitted Bradway to do what he did best - evaluate talent and make personnel decisions. Tannenbaum's well-rounded experience, in fact, helped him to replace Bradway as the Jets' GM in 2006, with Bradway returning to a scouting role with the Jets.

Tannenbaum, early on his tenure as GM, explained the importance of understanding the Salary Cap: "[e]very decision has ramifications, and that's probably the most important part of my job, to make sure we understand those ramifications . . . so that when we re-sign Chad Pennington or Curtis Martin or Shaun Ellis . . . (I say) 'now if we do this, here's what we can't do." 122

Again, the importance of the Salary Cap cannot be understated. Baltimore Ravens General Manager Ozzie Newsome once said he did not "know of any change that has come along and affected pro football as much."123 Former Giants General Manager Ernie Accorsi went further by explaining that the Salary Cap "governs everything; it's the last thing I think about when I go to bed and the first thing I think about when I wake up."124

\section{Rookie Contracts}

A rookie, as most everyone is aware, is "a person who has never before signed a Player Contract with an NFL Club."125 Drafting of rookies is one of a GM's most important jobs, and, until recently, ensuring that you could sign your top rookies without too much acrimony was also an important job.

119. See New York Jets Interactive Media Guide, http://www.newyorkjets.com/ $\mathrm{ms} /$ media-guide/2012/html/Bradway,-Terry.html (stating Bradway's experience).

120. See New York Jets Interactive Media Guide, http://www.newyorkjets.com/ $\mathrm{ms} /$ media-guide/2012/html/Tannenbaum,-Mike-1.html (stating Tannenbaum's experience).

121. See New York Jets Interactive Media Guide, http://www.newyorkjets.com/ $\mathrm{ms} /$ media-guide/2012/html/Tannenbaum,-Mike-2.html (stating Tannenbaum's experience).

122. See Kimberly Jones, They are all in this together, Newark Star Ledger, Jan. 31, 2005, at 44 (identifying implications of adding salary).

123. See John Eisenberg, Budget Ball, BaltimoreSun.com (November 3, 2002), http://articles.baltimoresun.com/2002-11-03/sports/0211030318_1_ravens-salarycap-super-bowl (supporting salary cap's significance).

124. See id. (further supporting salary cap's significance).

125. 2011 CBA, supra note 63, at art. 1. $§ 1$. 
Rookie compensation had been an increasingly contentious issue entering the 2011 CBA negotiations. The 2010 first overall pick, Sam Bradford, agreed to a six-year, $\$ 78$ million contract with the St. Louis Rams, including $\$ 50$ million guaranteed. ${ }^{126}$ By comparison, Tom Brady, a three-time Super Bowl champion and twotime MVP, received only a four-year, $\$ 72$ million contract with $\$ 48.5$ million guaranteed from the New England Patriots prior to the 2010 season. ${ }^{127}$ As a result, Clubs often looked to trade their high draft picks to avoid guaranteeing an unproven rookie tens of millions of dollars. ${ }^{128}$

The exorbitant sums being paid each year to rookies may have created the false impression that there was no limit on rookie compensation. However, the $2006 \mathrm{CBA}$ and the preceding $2001 \mathrm{CBA}$ included an Entering Player Pool that was the total amount of money that could be paid to drafted rookies. ${ }^{129}$ Each Club was provided the maximum Salary Cap charge (the Rookie Allocation) it could incur for that League Year. ${ }^{130}$ The Rookie Allocation was determined based on a formula agreed to by the NFL and NFLPA that accounted for the number, round, and position in round of the Club's draft picks in that year's NFL Draft. ${ }^{131}$ The formula designates a certain Salary Cap charge for each drafted player. The combined Salary Cap charges for each Club make up that Club's Rookie Allocation.

The 2011 CBA dramatically overhauled and limited the manner in which rookies are compensated. The Entering Player Pool remains-relabeled the Total Rookie Compensation Pool- and increases along with the Salary Cap up to five percent plus fifty percent of any increase over five percent. ${ }^{132}$ However, the 2011 CBA removed nearly all of the flexibility creative GMs and agents previously used to inflate rookie compensation within the new Total Rookie Compensation Pool.

126. See Adam Schefter, Chris Mortenson \& The Associated Press, Rams Give Bradford 50M Guaranteed, ESPN (July 31, 2010, 9:09 AM), http://sports.espn.go. $\mathrm{com} / \mathrm{nfl} / \mathrm{news} /$ story?id=5425041 (discussing Bradford's rookie salary).

127. See Adam Shefter, Mike Reiss, and Associated Press, Tom Brady Signs Extension, ESPN (Sept. 11, 2010, 3:13 PM), http://sports.espn.go.com/boston/nfl/ news/story?id=5552561 (discussing Brady's lower salary).

128. See Gregg Rosenthal, Talk Increases that Rams Would Trade Down on the Cheap, ProFootballTalk (Apr. 20, 2010, 6:53 AM), http://profootballtalk.nbc sports.com/2010/04/20/talk-increases-that-rams-would-trade-down-on-the-cheap/

129. See 2006 CBA, supra note 73 , at art. XVII $\S 1$ (a).

130. See id. at art. XVII $\S 3$.

131. See id.

132. See 2011 CBA, supra note 63 , at art. $7 \S 2(a)$. 
Rookie contract lengths under the 2011 CBA are "fixed and unalterable."133 Rookies drafted in the first round are limited to four-year contracts with a Club option for a fifth year. ${ }^{134}$ Under the 2006 CBA, rookies drafted in the first 16 picks could sign six-year contracts and rookies drafted in picks 16 through 32 could sign fiveyear contracts. ${ }^{135}$ Rookies drafted in rounds two through seven must now sign four-year deals. ${ }^{136}$ Previously, under the 2006 CBA, rookies in rounds two through seven were limited to four-year deals, but they were not mandatory. ${ }^{137}$ Additionally, Clubs will hold an option on their first round picks for a fifth year. ${ }^{138}$

The 2011 CBA continues only to restrict player compensation during the first year of the contract. Nevertheless, circumvention of the Rookie Compensation Pool's purpose is nearly impossible due to the restricted contract lengths and the prohibition on previously used mechanisms. The 2011 CBA specifically prohibits "option bonuses, option exercise fees, option nonexercise fees, Salary Advances . . voidable year(s) provisions, buybacks of voidable year(s) provisions, and any "contract with the contract" (i.e. terms and conditions of a contemplated superseding contract within the Rookie Contract)." In addition, the 25 Percent Rule, barring a player's Salary Cap charge to grow by more than twenty-five percent per year unless he was being paid the minimum Paragraph 5 salaries, remains. ${ }^{139}$

Most importantly, the Rookie Compensation Pool was clearly reduced from years past. The new rookie compensation system resulted in 2011 first overall pick Cam Newton agreeing to a four-year fully guaranteed contract for $\$ 22,025,498$ with the Carolina Panthers, ${ }^{140}$ representing a nearly $\$ 28$ million decrease in guaranteed money compared to Sam Bradford's 2010 contract.

133. See id. at $\S 3$ (a) (discussing rookie contracts under $2011 \mathrm{CBA}$ ).

134. See id. (describing impact of 2011 CBA on rookies).

135. See 2006 CBA, supra note 73 , at art. XVII $\S 5$ (describing previous limitations on rookies under previous CBA).

136. See $2011 \mathrm{CBA}$, supra note 63, at art. $7 \S 3(\mathrm{a})$ (illustrating changes between 2006 and 2011 CBAs).

137. See 2006 CBA, supra note 73 , at art. XVII $\S 5$ (commenting previous limitation under $2006 \mathrm{CBA})$.

138. See 2011 CBA, supra note 63 , at art. $7, \S 7$ (providing additional difference between 2006 and 2011 CBA).

139. See id. $\S 3(\mathrm{e})$ (stating 25 Percent Rule remains in 2011 CBA).

140. See Michael David Smith, Cam Newton, Panthers Agree to Four Year, $\$ 22$ million Contract, ProFootball Talk.com (July 29, 2011, 6:35 PM), http://profootball talk.nbcsports.com/2011/07/29/cam-newton-panthers-agree-to-four-year-22-million-contract/ (describing Cam Newton's contract with Carolina Panthers). 
Holdouts, whereby a rookie refuses to report to training camp until his contract demands are met, were a principal reason rookie contract amounts and structures were significantly curtailed in the 2011 CBA. Rookie holdouts became commonplace in the years leading up to the $2011 \mathrm{CBA}$ as first round compensation massively outgrew the compensation of other rookies. For example, in 2009, former Texas Tech wide receiver and tenth overall pick Michael Crabtree held out until the eighth week of the regular season before agreeing to a six-year deal with the San Francisco 49ers. Crabtree was unhappy with his overall draft slot and potential compensation and instead demanded a package that was worth more than the seventh overall selection, former Maryland wide receiver Darrius Hayward-Bey, drafted by the Oakland Raiders. ${ }^{141}$ Crabtree's only leverage was to threaten not to play the 2009 season and enter the 2010 draft in hopes of obtaining the contract he wanted. The 49ers were forced to find creative ways to make Crabtree happy without disrupting the slotting system that is part of NFL rookie contract negotiations. ${ }^{142}$

In general, the new rookie compensation system significantly limits the scope of rookie contract negotiations, permissible provisions and thus holdouts. The new system is much closer to the system used in the NBA, in which each draft position is specifically allocated a salary. ${ }^{143}$ The largely predetermined compensation structure will greatly reduce the threat of rookie holdouts, as players will have little choice or leverage in negotiating how much they want to make. ${ }^{144}$

141. See Rookie WR Crabtree ends holdout, signs six-year deal with 49ers, NFL, http:/ /www.nfl.com/news/story?id=09000d5d81339261\&template=with-video-with-comments\&confirm=true (updated Oct. 8, 2009, 4:27 PM) (outlining Michael Crabtree's holdout and subsequent contract with San Francisco 49ers).

142. See Peter King, Monday Morning $Q B$, Sports Illustrated, http://sports illustrated.cnn.com/2009/writers/peter_king/08/16/mmqb/2.html\#ixzz1KjL9dx Y1 (updated Aug. 17, 2009, 12:08 P.M.) ("The NFL has a slotting system that is ever-so-slightly malleable, where a player who gets drafted one spot lower than another player occasionally gets a smidgeon of a better deal. And sometimes a quarterback gets an above-market deal. But position players and non-quarterback skill players are slotted, and despite the efforts of agents to break the slotting system when picked lower than the agent or player thinks he should be picked, the league mostly holds firm.").

143. See Collective Bargaining Agreement Between National Basketball Association and the National Basketball Players Association, art. VIII (b) (i) [hereinafter 2005 NBA-CBA]; 2005 NBA-CBA ex. B (comparing new CBA to system in NBA).

144. See Mike Florio, Under New CBA, Rookies Won't Have Much of a Reason to Holdout, ProFootballTalk.com (July 23, 2011, 6:57 PM), http://profootballtalk. nbcsports.com/2011/07/23/under-new-cba-rookies-wont-have-much-of-a-reasonto-hold-out/ (predicting impact of predetermined compensation structure on holdouts by rookies). 
Assuming a player has successfully been drafted, signed his rookie contract, made the Club and played for the Club, the next question becomes when can the player execute a new and improved contract. Rookie contracts previously could not be renegotiated until after the player's second season. ${ }^{145}$ Consequently, players had to wait at least until after their second year to consider holding out for purposes of obtaining a new contract. Some Clubs - notably the Philadelphia Eagles - renegotiated rookie contracts after the second year believing they could negotiate a longterm deal at a lower salary than if the player were closer to free agency. ${ }^{146}$ This strategy, although potentially cost-saving, also invited young players to demand higher salaries, whether privately or in the media, based on limited credentials. The 2011 CBA has further limited the leverage of rookies who have outperformed their contracts by prohibiting renegotiation of rookie contracts until after a player's third season. ${ }^{147}$ The type of contract a player can negotiate as a veteran is discussed below.

\section{Veteran Contracts}

A "Veteran" is any "player who has signed at least one Player Contract with an NFL Club." 148 The different types of veterans and their ability to sign contracts is more complicated.

Players with less than three accrued seasons are known as "Exclusive Rights Players" and can only negotiate with their previous Club, provided the Club "tenders" or offers the player a one year contract with the minimum Paragraph 5 Salary by March 1. If the previous team has not tendered the player by that date, the player is free to sign with any team without penalty or compensation from his prior Club. ${ }^{149}$ Exclusive Rights Players generally consist of young players signed to one or two-year deals, desperate to stay in the NFL.

A player gains a little more leverage once he has played three seasons in the NFL. If a player's contract expires after his third season but before his fourth, he is a "Restricted Free Agent."150 A

145. See 2006 CBA, supra note 73, at art. XVII $\$ 4(i)$ (describing previous limitations under $2006 \mathrm{CBA})$.

146. See Greg Rosenthal, New CBA Limits Early Renegotiated Contracts, ProFootBALLTALk.COM (July 25, 2011, 10:26 PM), http://profootballtalk.nbcsports.com/ 2011/07/25/new-cba-limits-early-renegotiated-contracts/ (describing Philadelphia Eagles strategy for resigning players).

147. See $2011 \mathrm{CBA}$, supra note 63 , at art. $7 \S 3(\mathrm{k})(\mathrm{i})$ (stating requirement).

148. Id. at art. 1 .

149. See id. at art. $9, \S 1$ (a) (stating rule).

150. See id. at art. $9, \S 2$ (stating definition). 
Restricted Free Agent is "completely free to negotiate and sign a Player Contract with any Club, and any Club shall be completely free to negotiate and sign a Player Contract with any such player, subject to [certain] restrictions." 151 Those restrictions provide the player's prior Club the right to match any offer made to the player and to receive compensation if the player signs with a new Club.

The dance begins when the prior Club tenders the player a one-year contract with a certain Paragraph 5 Salary. The compensation the new Club would have to pay is based on that offer. If, in 2012 , the prior Club offered merely a one-year contract for $\$ 1.2$ million, it only retained a right of first refusal. ${ }^{152}$ If the prior Club offered a one-year deal of $\$ 2.611$ million, it was entitled to a right of first refusal and one first round draft pick. ${ }^{153}$ GMs must evaluate the player's contribution to the team and apply a tender offer accordingly.

Moreover, GMs must be astute in their talent evaluations if they choose to sign a Restricted Free Agent and risk losing a draft pick. The compensation scheme has ultimately resulted in little or no Restricted Free Agents changing teams in recent years.

A significant moment in an NFL player's career is when he reaches "Unrestricted Free Agency." An Unrestricted Free Agent is a player with at least four accrued seasons and an expired contract. ${ }^{154}$ Unrestricted Free Agents are free to negotiate with any Club and offer their services to the highest bidder.

The free agency period is not only exciting and anxious for the players but also for the GMs. A new League Year begins each year in early March. As soon as the clock strikes 12 a.m. eastern standard time on the new League Year, all Unrestricted Free Agents are free to sign with any team of their choice and Clubs, coaches, and GMs can begin wooing the Unrestricted Free Agents.

Prior to the opening of free agency, it is important for the GM and his staff to coordinate a plan. The GM, with the help of his coaches and scouts, must identify the particular players they are interested in signing and the priority of attack. The GM must then check with the Director of Football Administration to get a sense of how much each player is likely to command on the open market and to ascertain what the Club's Salary Cap and financial position can handle. It is then up to the GM and typically the head coach to

151. See id. at art. $9, \S 2$.

152. See id. at art. 9, § 2(b) (1) (explaining rule).

153. See id. at art. 9, §2(b) (4) (explaining rule).

154. See id. at art. 9, §1(a) (defining term). 
make what is essentially a recruiting call at midnight to the player and his agent, offering their best pitch why the player should be interested in joining their Club.

Before Clubs even begin thinking about signing Unrestricted Free Agents, they generally focus on resigning their own impending Unrestricted Free Agents. After the Super Bowl in early February, Clubs generally have about a month to negotiate new deals with their impending Unrestricted Free Agents, during which time the player cannot yet talk to other Clubs.

Besides simply offering an enticing deal to the player, Clubs can also use the Franchise "tag" in an effort to retain the player's services. Clubs are permitted to designate one player as a "Franchise Player" by tendering to the player a contract with specific terms. ${ }^{155}$

There are two types of Franchise Player tags. First, if the Club is willing to let the player talk to other Clubs, it can tender the Nonexclusive Franchise Tender in which the Club offers the player a one year contract for the average of the five largest prior season salaries for players at the same position, or $120 \%$ of the player's prior season salary, whichever is higher. ${ }^{156}$ If the player signs with a new Club, the new Club must compensate the prior Club with two first round draft picks. ${ }^{157}$ No player ever designated as Franchise Player has ever signed with another Club as a result of this high compensation.

Second, if the Club does not want the player to have the opportunity to discuss a contract with another Club, it can make an Exclusive Franchise Tender. The Exclusive Franchise Tender requires the Club to offer a one year contract for the average of the five largest salaries at the same position as of the end of the Restricted Free Agent Signing Period. ${ }^{158}$ The Restricted Free Agent Signing Period extends into the new League Year and thus includes any new contracts entered into in the offseason prior to the new League Year, potentially raising the tender amount.

Designating a Franchise Player becomes a tricky political situation for the GM. On the one hand, the GM is telling the player that the Club believes he is one of the top players at his position and an important part of the Club. On the other, the GM is essentially saying that the Club is unsure of the player's long-term prospects

155. See id. at art. 10, $\$ 1$ (explaining franchise tags).

156. See id. at art. $10 \S 2$ (a) (i) (explaining first type of franchise tag).

157. See id. at art. $10 \S 2$ (a) (i) (stating rule).

158. See id. at art. $10 \S 2$ (a) (ii) (discussing second type of franchise tag). 
and does not want to commit to the player. Consequently, Franchise Players often strive to negotiate a long-term deal with the leverage that they will not sign the tender and report to training camp on time. In the 2012 offseason, twenty-one players were designated as Franchise Players. ${ }^{159}$ Ultimately, twelve players reached long-term deals with their Clubs while nine players were unable to do so and were forced to sign the one-year tender. ${ }^{160}$

An essential party to any contract negotiation is the player's NFLPA certified contract advisor, or agent. The National Labor Relations Act dictates that an employee's union, such as the NFLPA, is the "exclusive representative[ ]" of employees concerning the employee's "rates of pay, wages, hours of employment, or other conditions of employment." 161 The NFLPA, however, like the other unions in professional sports, has chosen to certify agents to represent players in contract negotiations. Agents undergo a fairly rigorous certification process and their compensation is generally limited to $3 \%$ of the player's contract. ${ }^{162}$

A GM's relationship with agents can be essential not only in recruiting Unrestricted Free Agents, but also in keeping a Club's current players happy and performing at a high level. "A lot of it starts with your relationships with the individual agents," Former Denver Broncos GM Ted Sundquist said. "It's very important to spread yourself broadly when it comes to agents, because you never know who you're going to have to work with to get the player you want for your team." 163 Tannenbaum echoed those sentiments, explaining that strong relationships with agents are essential to obtaining industry information and, specifically, information about players that the Club might not otherwise be able to obtain. ${ }^{164}$ Agents are particularly adept at providing information on prospective draft picks, which can have an inescapable impact on a GM's career. ${ }^{165}$

159. See Michael David Smith, 2012 NFL franchise players, NBC Sports (July 16, 2012), http://profootballtalk.nbcsports.com/2012/07/16/2012-nfl-franchise-players/ (listing "2012 franchise players").

160. See id. (listing 2012 franchise players).

161. NLRA, $\S 9(\mathrm{a})$.

162. See NFL Players Association, NFLPA Regulations Governing Contract Advisors, at $\S 4(\mathrm{~B})$, NFL Players Association (June 2012), http://images.nflplayers. $\mathrm{com} / \mathrm{mediaResources} /$ files/PDFs/SCAA/2012_NFLPA_Regulations_Contract_ Advisors.pdf (discussing agent certification).

163. See Anthony Cotton, Good idea to keep agents in touch, Denv. Post, Sept. 18, 2005, at J05, available at 2005 WLNR 14766944.

164. Interview with Mike Tannenbaum, former General Manager, New York Jets of the NFL (March 28, 2013).

165. See id. 
GMs generally develop relationships with agents long before becoming GM. When Phil Emery was hired as the Bears' GM just prior to the opening of free agency in 2012, it was seen as a plus that he already had strong relationships with many agents "from his long run as a college scouting director and area scout."166 Emery, while working as a scout, would have also used those relationships with agents to gain valuable information about college players the Bears were considering drafting. Agents will often have a chance to get to know the college player better and gain a better sense of what type of person the kid is.

\section{B. Roster Management}

A GM's first priority is to put players on the field that will win football games. Regardless of all the other duties of a GM, at the end of the day a GM must be able to recognize talent. To that end, as will be discussed throughout this article, GMs generally delegate and supervise many important Club functions so that they can focus on player personnel decisions.

Shaping an NFL roster includes various important dates. At the conclusion of one season, the GM will generally hold an organizational meeting where the team's scouts (Professional and College), coaches, and even medical personnel come together to discuss the previous season, the makeup of the Club and plan offseason priorities. ${ }^{167}$ The GM and his team of scouts will evaluate and grade the current players and compare these grades to the upcoming free agent market. From these grades, the GM will work with his Salary Cap specialist to determine where the team should allocate its financial resources, whether it be locking up young talent to long-term contracts, re-signing pending free agents, or to focus on acquiring other free agents.

As discussed above, the GM will then lead the Club into the free agency period in early March, seeking to sign marquee free agents while also seeking to find solid players at less celebrated positions such as offensive line and reliable backups to fill out the 53man roster. The unheralded signings might not make front page news on the day the ink dries, but can make or break a GM and a Club in any given season.

166. See Brad Briggs, Bears' Emery getting down to business, CHI. TriB., Feb. 23, 2012, at 7, available at 2012 WLNR 3882603.

167. See Peter King, The Next Step is the Hardest, Sports Illustrated, Vol. 109, Issue 9, Sept. 8, 2008, at 50-58 (discussing Cleveland Browns offseason strategy). 
Before the Club gets to its regular season 53-man roster, the Club can carry as many 90 players on its roster during the offseason and training camp. ${ }^{168}$ Consequently, Clubs have many personnel decisions to make in filling and then paring down the roster.

While some teams add big pieces during free agency, other teams necessarily lose key players. Former Indianapolis Colts, Panthers, and Buffalo Bills GM Bill Polian has a unique view of these losses. He explained that he had learned from baseball executives such as Jim Hendry, formerly of the Chicago Cubs, and Theo Epstein, formerly of the Boston Red Sox and currently of the Cubs. "They don't worry about losing free agents every year[,]" Polian said. "[The Colts] lose the off-season every year. The baseball people have helped me understand it's meaningless."

"There are different ways you can acquire players in the National Football League," says Cowboys Head Coach Jason Garrett. "The draft is a big part of it. Signing your own players and also signing free agents is a big part of it as well." 169 Polian, in contrast, often let very good players leave the Club as free agents to be replaced by younger players in the NFL Draft. Polian believed in spending the majority of his budget on indispensable players and then trusting his scouts to find winning players at other positions. ${ }^{170}$ Polian achieved considerable success with one indispensable player, quarterback Peyton Manning, during his tenure with the Colts, including the 2006 Super Bowl championship. As free agency begins to settle, all eyes turn to the NFL Draft.

\section{NFL Draft}

The NFL Draft consists of seven rounds, in which each Club is initially allotted one pick. ${ }^{171}$ Clubs can be awarded additional compensatory selections based on the results of free agency, according to a formula agreed to by the NFL and NFLPA. ${ }^{172}$ The NFL Draft is a Club's principal opportunity to get cheap, young and exciting talent. Poor drafts, however, can also doom a GM and Club. This section will discuss the mechanics of the NFL Draft, while the Col-

168. See art. $11 \S 3(\mathrm{~g})$.

169. See Tom Orsborn, Cowboy's to rely on Ryan's ability, FOX SpORTs (May 4, 2011), http://msn.foxsports.com/nfl/story/Cowboys-to-rely-on-Ryans-abilityJonesUnit-will-thrive-under-defensive-guru-76931430 (quoting Cowboys Coach).

170. See Peter King, The P's Have it, Sports Illustrated, Vol. 107, Issue 19, Nov. 12, 2007, at 38 (discussing Buffalo Bills GM, Bill Polian).

171. See art. $6 \S 2(a)$.

172. See art. $6 \S 10$. 
lege Scouting section below will discuss how Clubs make their draft selections.

Many argue that the NFL Draft is the most important "building block" for a GM.173 Former NFL General Manager Bobby Beathard, whose teams went to seven Super Bowls, said of the Draft, "I think it is the foundation of the entire league . . . [i] t's the most important part of putting your team together. You build everything around the draft. You mold your team around the draft. For me, free agency, what you are getting sometimes, is too risky." 174

Following the Green Bay Packers' 2011 Super Bowl victory, General Manager Ted Thompson was lauded for his roster management, especially his work in the Draft. ${ }^{175}$ From 2006 to 2011, Thompson made 57 Draft selections, 28 of which were still on the roster for the Club's Super Bowl victory, including 13 starters. ${ }^{176}$

The Packers were dethroned the next season by a Club with similar Draft success, the Giants. The Giants, led by GM Jerry Reese since 2007, have also been praised for his Draft selections. Reese has been successful not only with his early round selections, such as first-rounders Aaron Ross (2007), Kenny Phillips (2008), Hakeem Nicks (2009), and Jason Pierre-Paul (2010), but has also found several later round gems that contributed mightily to the Giants' 2008 and 2012 Super Bowl victories, such as Ahmad Bradshaw (7th Round in 2007), Kevin Boss (5th Round in 2007), and Mario Manningham (3rd Round in 2008). ${ }^{177}$

173. See Larry Weisman, Build a Foundation? Start by stockpiling draft picks, WASHINGTON REDSkins (Mar. 15, 2011), http://www.redskins.com/news-andevents/article-1/Build-a-Foundation-Start-By-Stockpiling-Draft-Picks/847a9bb4-d0 c9-40e2-935a-3be7c9981365 (discussing importance of NFL draft).

174. See Thomas George, An inside look on how teams approach the NFL draft, NFL (Apr. 22, 2009), (quoting NFL General Manager Bobby Beathard).

175. See Tom Oates, Can't Pick on Thompson for His Picks, Wis. ST. J., Dec. 7, 2010, at D1, available at 2010 WLNR 24224437 (praising Thompson's draft approach and selections).

176. Compare Green Bay Packers Draft History, NFL, http://www.nfl.com/draft/ history/fulldraft?teamId=1800\&type=team (providing draft history of Packers), with 2010 Green Bay Packers Statistics and Players, Pro-Football Reference.com, http://www.pro-football-reference.com/teams/gnb/2010.htm (providing roster for 2010 Packers).

177. Ross signed with the Jacksonville Jaguars prior to the 2012 season. Phillips played in 49 games for the Giants between 2008 and 2011, starting 36 and recording eight interceptions). Nicks played in 42 games for the Giants between 2009 and 2011, starting 33, during which time he caught 206 passes for 3,072 yards and 24 touchdowns. Pierre-Paul exploded onto the scene in the 2011 season, recording 86 tackles, and 16.5 sacks, earning Pro Bowl and First Team All-Pro Honors. Bradshaw played in 70 games for the Giants from 2007 through 2011, sharing running back duties with Brandon Jacobs. During that time, Bradshaw accumulated 3,295 rushing yards and 30 touchdowns. Boss played in 58 games for the 
The Giants' success likely speaks well of Reese's managerial efforts in light of the comments from his predecessor and mentor, Ernie Accorsi. Accorsi, in discussing his decision to defer to Reese and coach Tom Coughlin's preference for defensive end Matthias Kiwanuka during the 2006 Draft, stated: "I decided to let them have their way. A GM shouldn't always be heavy-handed. The front office is a team, too. This was good for the team. And, obviously, it wasn't a franchise-changing decision. If it had been a franchisechanging decision, I'd have ignored everybody and insisted on having my own way." 178

Clubs take different approaches to handling their allotted draft picks. The Patriots, five-time AFC Champions between 2001 and 2011, led the NFL with a total of 51 total draft picks between 2006 and 2010. ${ }^{179}$ In contrast, the Patriots' rival, the Jets, had the least number of draft picks with only 27. ${ }^{180}$

Rather than bring in a large number of rookies, the Jets, instead, have focused on trading their draft picks so as to allow the team to move up in the Draft where they can draft better players. For example, in 2007, the Jets traded picks in the first round (25th overall), second round (59th), and fifth round (164th) to the Panthers for the Panthers' 14th overall slot and a sixth round pick. ${ }^{181}$ The Jets used the 14 th overall pick to draft Darrelle Revis, now a perennial Pro Bowler cornerback. Then, in 2009, the Jets traded three players, their first round pick (17th overall), and second round pick (52nd) for the Cleveland Browns' fifth overall pick, which the Jets used to draft quarterback Mark Sanchez. ${ }^{182}$

The Jets' strategy presupposes that they are able to find a trade partner on or before draft day. Luckily, over the years, these part-

Giants from 2007 through 2010, starting 45, during which time he caught 119 passes for 1,600 yards and 18 touchdowns. Manningham played in 59 games for the Giants from 2008 through 2011, starting 28, during which time he caught 160 passes for 2,315 yards and 18 touchdowns.

178. Tom Callahan, The GM 17 (Broadway Books, The Crown Publishing Group 2008).

179. See Matt Maiocco, Five Year Study of NFL Drafts, Apr. 4, 2011,http://www. chiefsplanet.com/BB/archive/index.php/t-243668.html (ranking draft selections for all thirty-two teams in past five years). .

180. See id.

181. See Karen Crouse, Jets Trade Up to Draft Revis With 14th Pick, N.Y. TimES (Apr. 29, 2007), http://www.nytimes.com/2007/04/29/sports/football/29jets. html (providing insight to Jets' draft-picking mentality and plan).

182. See 2010 NFL Draft Pick Transactions, ProSportTransactions.com, last visited Mar. 13, 2013 http://www.prosportstransactions.com/football/Draft Trades/Years/2010.htm (listing all draft picks and transactions at $2010 \mathrm{draft}$, including those of Jets). 
ners have not been hard to find. In the 2010 offseason and Draft there were 86 trades involving 109 draft picks. ${ }^{183}$ Forty-four of these trades involved a total of 55 players, while the remaining 42 trades were draft picks only. ${ }^{184}$

Trades of top ten draft positions, however, remained rare until the 2011 CBA. Between 2008 and 2011 there were only five trades involving top ten draft positions. ${ }^{185}$ The limited mobility at the top of the draft was due to two main factors: (1) the compensation of top ten selections; and (2) the perceived "value" of a top ten pick.

Rookie compensation had increased so dramatically that Clubs actually preferred to draft later in the first round rather than be forced to guarantee tens of millions of dollars to unproven rookies. The 2011 CBA resolved this issue by reigning in rookie compensation, as discussed above. Not surprisingly then, there were six trades involving top ten draft selections in the 2012 Draft. ${ }^{186}$

The perceived value of a top ten overall pick stems from the Cowboys' creation and use of the "Trade Value Chart." In the 1991 NFL Draft, coming off a 7-9 season, the Cowboys had ten picks in the first four rounds. ${ }^{187}$ Consequently, it seemed likely that the Cowboys would be active in the trade market during the Draft. However, Cowboys coach Jimmy Johnson lamented that he had no way of knowing how much certain picks were worth, e.g., is a third round draft pick more valuable than fifth and seventh round picks? 188

Mike McCoy, a Cowboys executive and minority owner, set out to create a solution to Johnson's problem. McCoy examined all NFL Draft day trades in the previous four years to determine how

183. See id (describing all trades between teams during 2010 draft).

184. See id (detailing all trades made by teams for 2010 draft transactions).

185. See History: Pro Football Draft History, Pro Football Hall Of Fame, http:/ /www.profootballhof.com/history/general/draft/index.aspx (last visited Mar. 22, 2013) (providing in-depth coverage of draft picks from 1930's to present day). The trades resulted in: the New Orleans Saints drafting Sedrick Ellis with the seventh overall pick in 2007; the Jacksonville Jaguars drafting Derrick Harvey with the eighth overall pick in 2007; the New England Patriots drafting Jerod Mayo with the tenth overall pick in 2007; the Jets' trade for Sanchez in 2008; and the Atlanta Falcons drafting Julio Jones with the sixth overall pick in 2011. See id.

186. See History: Pro Football Draft History, supra note 185 (explaining that Clubs, picks, and players involved were: Washington Redskins, 2nd overall, Robert Griffin, III; Cleveland Browns, third overall, Trent Richardson; Minnesota Vikings, 4th overall, Matt Kalil; Jacksonville Jaguars, 5th overall, Justin Blackmon; Dallas Cowboys, 6th overall, Morris Claiborne; and Tampa Bay Buccaneers, 7th overall, Mark Barron).

187. See Tobias J. Moskowitz and L. Jon Wertheim, Scorecasting 174 (2011) (describing situation).

188. See id. (illustrating situation). 
Clubs had valued certain positions in the Draft. ${ }^{189}$ McCoy did not seek to determine whether the Clubs' perceived valuations were accurate but sought to examine how Clubs had acted in the past. ${ }^{190}$ McCoy's end product was the Trade Value Chart which assigned numerical values to each pick in the Draft. For example, the first overall pick is worth 3,000 points, the second overall pick is 2,600 points, the first pick of the second round is 580 points and so on, until the last pick is worth 0.4 points. ${ }^{191}$

The Cowboys used the Trade Value Chart during the 1991 Draft to draft a total of 17 players. ${ }^{192}$ The Cowboys improved to 115 in 1991 and won the Super Bowl in 1992. McCoy's Trade Value Chart became legendary. Cowboys assistants took promotions with other Clubs and made sure to take the Trade Value Chart with them, cementing its use around the NFL.

Despite its widespread use, the Trade Value Chart has proven to be inaccurate and unreliable. Cade Massey of Duke University and Richard Thaler of the University of Chicago compared the value Clubs placed on certain Draft positions - based on what the Club gave up to get to that position - with the actual performance of the players drafted at that position. ${ }^{193}$ The research indicated that Clubs erroneously discount future picks and overvalue early picks. The Trade Value Chart claims that the top overall pick is 3,000 points and the first pick of the second round is only worth 580 - meaning you would need at least five picks at the top of the second round to be able to trade for the first overall pick. This is clearly wrong. The first overall pick is, on average, not even twice as good as the first pick of the second round. ${ }^{194}$ These types of errors permeated the Trade Value Chart, indicating that GMs must ensure that their Draft day decisions are based on reliable analysis.

\section{Undrafted Free Agents}

Each year approximately 255 players have the privilege of being selected in the NFL Draft. However, these players are not the totality of new talent for Clubs and GMs to consider. Any prospective draftee that goes undrafted immediately becomes eligible to

189. See id. (describing process).

190. See id. (explaining analysis).

191. See id. (demonstrating point system).

192. See id. (noting Dallas had ten picks in first four rounds of 1991 draft).

193. See id. at 180.

194. See id. at 181. 
negotiate and sign a Player Contract with any Club. ${ }^{195}$ These undrafted free agents are the great unknowns of the NFL personnel selection process.

Hundreds of undrafted free agents pour into NFL mini-camps and training camps each offseason desperate to win a job on the Club. While only a dozen or two actually succeed in making the Club, there is no shortage of undrafted free agent success stories. Notable undrafted free agents include two-time NFL MVP and Super Bowl MVP quarterback Kurt Warner, six time Pro Bowl tight end Antonio Gates, Victor Cruz, the leading receiver for the 2012 Super Bowl Champion Giants, and two-time Super Bowl Champion and 2008 NFL Defensive Player of the Year James Harrison. ${ }^{196}$

Clubs generally use signing bonuses to attract the most highly sought after undrafted free agents. A player could gauge which Club was most interested in the player being a part of the Club by the offer made. The 2011 CBA, however, limits Clubs to a total of $\$ 75,000$ in signing bonuses to be paid to undrafted rookies, an amount to increase annually with the Rookie Compensation Pool. ${ }^{197}$ Clubs' interests are now less clear as a result of the cap on signing bonuses to undrafted players.

Failing to make the Club out of training camp is hardly the end of the road for undrafted free agents either. Undrafted free agents can sign with other teams, get tryouts or hopefully get signed to a Club's Practice Squad. A Practice Squad consists of eight players per Club, who, as the title indicates, practice with the Club but do not play in games. ${ }^{198}$ Practice Squad salaries were a minimum of $\$ 5,700$ per week during the 2012 season. ${ }^{199}$ Players are limited to

195. See $2011 \mathrm{CBA}$, supra note 63, at art. $6 \S 11$ (enabling all undrafted free agents unencumbered negotiation rights with teams).

196. See Gil Brandt, Warner Tops List of Best Undrafted Players of All Time, NFL.COM (Mar. 16, 2010), http://www.nfl.com/draft/story/09000d5d816fb4f0/ article/warner-tops-list-of-best-undrafted-players-of-all-time (ranking best undrafted free agents in past seventy-five drafts).

197. See $2011 \mathrm{CBA}$, supra note 63, at art. $7 \S 1$ (i) (outlining parameters for rookie compensation).

198. See 2011 CBA, supra note 63, at 160 (setting out league rules for practice squads and practice squad players)

199. See 2011 CBA, supra note 63, at 161 (listing minimum future salaries for practice squad players under the collective bargaining agreement by year). Practice Squad salaries were a part of the contentious litigation between the NFL and NFLPA in the late 1980s. In Brown v. Pro Football, Inc., the NFLPA challenged the Clubs' unilateral agreement to restrict practice squad salaries to $\$ 1,000$ per week. See 782 F. Supp. 125, 127 (D.D.C. 1991). The NFLPA adamantly rejected the NFL's decision to impose the wage restrictions. See id. The district court, applying the Mackey test, determined that the wage restriction was not reached through arm's length bargaining and therefore was not protected by the labor 
three seasons on the Practice Squad, during which time they can sign with any other Club at any time. ${ }^{200}$

Undrafted free agents can help round out the back of the roster or even prove to be important contributors to a successful Club. Finding the diamonds in the rough are undoubtedly among a GM's finest and proudest moments. As Gil Brandt, the Cowboys' Vice President of Player Personnel from 1960 to 1988, explained in a 2010 article: "General Managers enjoy it when their first-round draft pick meets those lofty expectations. And it's a real bonus when mid to low-round selections exceed their expectations. Then there is the ultimate satisfaction of signing a player who was passed over entirely in the draft and seeing him become a productive pro." 201

\section{Waivers and Trades}

GMs are not done manipulating the roster once the Draft is complete and undrafted free agents are signed. GMs are always evaluating the roster and trying to bring in the best player to generate competition at every level. In his first year as GM of the Seattle Seahawks, John Schneider, along with new head coach Pete Carroll made 283 roster moves. ${ }^{202}$ The shuffling was largely to create competition for playing time. Carroll used the strategy to build teams that won two national titles in his nine seasons as a college coach at USC, and Schneider is following a similar blueprint to elevate a Club that won just nine games in the two seasons before he took over. ${ }^{203}$ Beyond the Draft and signing of free agents as discussed above, Clubs can also acquire players through waivers and trades.

Players with less than four years experience do not become unrestricted free agents upon their release from a Club. Instead, such players must pass through the NFL "waiver" system. ${ }^{204}$ Pursuant to

exemption. See id. However, the Supreme Court ultimately reversed the district court's decision in 1996 and determined that the NFL's unilateral imposition of the practice squad salary limitations was protected by the non-statutory labor exemption. See Brown v. Pro Football, Inc., 518 U.S 231 (1996) (reversing the district court's decision).

200. See 2011 CBA, supra note 63, at 160-161 (specifying limits under collective bargaining agreement for practice squad players).

201. See Brandt, supra note 196.

202. See Nate Davis, Seahawks happy to be late to party, 283 roster moves later, Carroll's club is hot but in no way overconfident, USA TODAY, Jan. 13, 2011, at 1C, available at 2011 WLNR 715505.

203. See Jim Trotter, It Could Happen, Sports Illustrated, Jan. 17, 2011, at 50 (discussing Seattle Seahawks' offseason personnel strategy).

204. See 2011 CBA, supra note 63, at 155 (describing and laying out rules for NFL waiver process). 
the waiver system, other Clubs will have the opportunity to claim the waived player and his contract with the prior Club. ${ }^{205}$ The waiver wire, as it is known, is especially important towards the ending of training camp when Clubs are trimming their rosters from ninety players down to fifty-three. GMs and their staff must be diligent in seeing which players have been waived, consult with their scouting personnel and coaches about the player, and ultimately make a decision whether to claim the player. Of course, claiming the player forces the Club to release or waive one of their own players to make room on the roster.

The Packers' success in the 1990s can be attributed in part to the Packers' attention to the waiver wire. Then Packers GM Ron Wolf had an agreement with then Packers head coach Mike Holmgren that the 51st to 53rd players could become expendable if Wolf saw someone on the waiver wire that was better. ${ }^{206}$

The waiver system is also meant to prevent Clubs from stashing young players on the injured reserve or physically unable to perform lists. Before a player with less than four years experience can be placed on one of these lists, he must be placed on waivers. ${ }^{207}$ There is thought to be an "unwritten rule" that Clubs do not claim other Club's injured players placed on waivers. ${ }^{208}$ The Patriots possibly violated this unwritten rule by claiming Giants injured tight end Jake Ballard during the 2012 offseason, after Ballard helped the Giants beat the Patriots in the Super Bowl. ${ }^{209}$

Trades, unlike in other sports, are among the least common ways a Club acquires new players. The Salary Cap rules associated with trades often make them prohibitive. As discussed earlier, a player's signing bonus is prorated over the life of his contract (up to five years) for Salary Cap purposes. For example, if a player signs a five-year deal with a $\$ 10$ million signing bonus, the bonus is pro-

205. See id. (explaining NFL's waiver process).

206. See Michael Lombardi, It's Complicated: How to get to the final 53-man roster, NFL (Aug. 30, 2010), http://www.nfl.com/news/story/09000d5d81ale654/printable/its-complicated-how-to-get-to-the-final-53man-roster (discussing agreement between Green Bay Packers' general manager and head coach).

207. See Christopher Gates, Waivers, The Practice Squad, and How It All Works, The Daily Norseman (Sept. 1, 2012), http://www.dailynorseman.com/2012/9/1/ 3284495/waivers-the-practice-squad-and-how-it-all-works (explaining how NFL waiver system works).

208. See Mike Florio, Giants' Gamble on Ballard Highlights The Risks of Waiving Injured Players, ProFootballTalk.com (June 12, 2012), http:// profootballtalk.nbc sports.com/2012/06/12/giants-gamble-on-ballard-highlights-risks-of-waiving-injured-players/.

209. See id. (discussing circumstances in which New England Patriots claimed former New York Giants Tight End off of waivers). 
rated at an annual value of $\$ 2$ million. The player's resulting Salary Cap charge for each season of the contract would be $\$ 2$ million, plus his Paragraph 5 salary and any other bonuses or incentives for that season. However, when a player is cut from the Club, the remaining prorated portions of his signing bonus "accelerate" forward into the season in which the player is cut. ${ }^{210}$ So in the previous example, if a player had played two years of the five-year contract but is cut prior to the third season, the Salary Cap charge related to his signing bonus would be $\$ 6$ million in the third year of the deal: the typical $\$ 2$ million annual proration, plus the remaining $\$ 4$ million in prorated signing bonus money for the final two years of the contract "accelerated" forward. This acceleration also occurs when a player is traded, thus requiring Clubs to absorb a possibly large Salary Cap hit.

Waivers ultimately become the key mechanism by which Clubs round out their rosters. Former Raiders personnel executive Michael Lombardi explained that "building the best possible team means having great players in every phase of football offense, defense and, most importantly, special teams." ${ }^{211}$ Entering week 3 of the preseason, teams have identified a core of forty players making up the offense and defense. ${ }^{212}$ The forty players will include a kicker, punter and long snapper, with the remaining members of the special teams unaccounted. ${ }^{213}$

Clubs generally avoid filling out the roster with veterans. Veterans with at least four years experience, if on the opening day roster, effectively have their salary guaranteed for that year. Such players are entitled to termination pay once in their career. ${ }^{214}$ Termination Pay provides to the released player "the unpaid balance of his Paragraph 5 Salary for that League Year."215 Thus, veterans of marginal talent can often hinder a Club's necessary flexibility in shuffling the back end of the roster.

210. See 2011 CBA, supra note 63, at 94 (explaining how cut players' salaries "accelerate" into future years' team salaries).

211. Lombardi, supra note 206.

212. See id. (explaining that by week 3 of NFL preseason, most teams will have identified core group of approximately forty players whose spots on their respective team's roster are secure).

213. See id. (explaining typical constitution of NFL roster by week 3 of preseason).

214. See 2011 CBA, supra note 63, at 157 (explaining players' eligibility for termination pay in NFL).

215. See 2011 CBA, supra note 63, at 157 (explaining amount of termination pay players will be eligible for). 


\section{Summary}

Successful management of the Draft is undoubtedly the most critical component of a GM's personnel decisions. Nevertheless, as discussed above, there are a variety of ways in which a GM can build a roster. Falcons GM Thomas Dimitoff explained that "[ $\mathrm{t}]$ here are some very, very talented players coming into this league through the draft, through free agency, and the easy thing to do is to bring in the most talented players whether they fit or don't fit. You can win that way, no question about it."216

Former Chiefs GM Scott Pioli, once Dimitroff's colleague with the Patriots, took a more cautious approach: "the key is sustainability. Do you want to build a team that will win once and then implode? I don't think that's the job. The job is to make the difficult decisions so you can build the kind of team that can be in position to win every single year."217

No matter the approach, an NFL GM clearly has a difficult job in terms of building a championship roster. He must balance the Salary Cap, determine when to pay veteran players and when to let them go, decide whom the Club will select in the Draft and what trades are necessary to do that, and finally he must also work with other GMs to see what, if any, trades are available to improve the roster. All these moves should work to build a roster of 90 players that provide the coaching staff with enough talent to install their game plans. The GM then must whittle that roster down to 53 players who have enough talent to perform on a high level on offense, defense and special teams while still providing depth at each position. All of this must occur while managing the personalities in the locker room and among the coaching staff. This is not possible alone and therefore great GM's surround themselves with talented scouts and personnel executives who can aid the GM in making the best decisions for the team, as is discussed below.

\section{Overseeing Scouting Department}

As explained above, roster management and personnel selection are crucial tasks for an NFL GM. At any given time during the regular season, there are nearly 2,000 players under contact with an

216. See Joe Posnanski, A Dream in the Making, Sports Illustrated, Dec. 6, 2010, at 88 (elaborating on processes used by team GMs to build rosters), available at http://sportsillustrated.cnn.com/vault/article/magazine/MAG1179410/index. htm. team).

217. See id. (exploring different approaches used by GMs when building their 
NFL Club either on the active/inactive list, injured reserve, or practice squad.218 During the preseason, when rosters are expanded to 90 players, there are nearly 3,000 players under contract. The number of players is further increased over time when you consider that, according to the NFLPA, the average NFL career is 3.5 years. ${ }^{219}$ An NFL Club must be aware of and have a scouting report on each and every player.

NFL GMs must build and manage a talented scouting staff to undertake this task. The best personnel developers in the NFL aren't all-knowing "gurus," but instead run great support staffs, former Tennessee Titans GM Floyd Reese writes. ${ }^{220}$ To this point, Tannenbaum considered himself the "point guard of information," making sure everyone in the organization was on the same page. Tannenbaum consequently believes being a good listener and being organized are two of the most important traits for a GM. ${ }^{221}$

NFL Clubs divide the scouting duties between their College Scouting Department and their Professional Scouting Department.

\section{College Scouting}

The number of college football players that NFL Clubs must scout each year is overwhelming. The NFL lacks an established minor league and thus looks to collegiate players to fill their ranks each year. The CBA dictates that players must be at least three years removed from their high school class' graduation in order to be eligible for the NFL draft. ${ }^{222}$ The pool of draft eligible players consists of seniors, juniors, and redshirt sophomores. With 124 teams playing in the Football Bowl Subdivision (formerly 1-A) and 122 teams playing in the Football Championship Subdivision (formerly 1-AA), there are thousands of draft eligible players each

218. See Robert Orlandini, How Many Players are in the NFL, LIVESTRONG.COM, Jul. 2, 2009, http://www.livestrong.com/article/15471-many-players-nfl/ (calculating 2,000 NFL players based on 32 teams employing 52 players).

219. See The Average NFL Player, BusinessWeek (Jan. 27, 2011), http://www. businessweek.com/magazine/content/11_06/b4214058615722.htm (providing general statistics of NFL players, including average salary, median player salary, average age, and average number of players on injured reserve).

220. See Floyd Reese, Best Talent Evaluators Take Rrisks, Make Hard Decisions, ESPN.cOM (Feb.26, 2008), http://sports.espn.go.com/nfl/draft08/columns/ story? columnist=reese_floyd\&id=3262379 (listing top five current NFL talent evaluators and explaining why each person made his personal list).

221. Interview with Mike Tannenbaum, former General Manager, New York Jets of the NFL (March 28, 2013).

222. See 2011 CBA, supra note 63, at 46 . 
year. ${ }^{223}$ Moreover, 41 players were drafted out of Division II, Division III, and the National Association of Intercollegiate Athletics (the NCAA's much smaller competitor) in the 2012 NFL Draft. ${ }^{224}$

Incredibly, NFL Clubs will seek to evaluate the professional prospects of each of these thousands of players. Reese explained that the arduous scouting process generally begins in the spring with the GM and the College Scouting Director sending a team of scouts across the country to see the collegians practice and play. ${ }^{225}$

An NFL scouting department consists of approximately 10-12 persons, about half of whom will be dedicated to college players. The college scouts generally focus on a particular area and/or conference(s), e.g., someone might be the "northeast" scout or be responsible for scouting the Southeastern Conference. Obviously, the better the player, the more times a scout, or even the GM, will go watch.

In addition to their own area scouts, most NFL Clubs also subscribe to one of two scouting services: National or BLESTO. BLESTO stands for Bears, Lions, Eagles and Steelers Talent Organization, although now approximately twelve teams use BLESTO. Both organizations employ scouts to do the same tasks as the area scouts and then create extensive reports about the players, including their "grades." 226

The GM and the scouting department are not only responsible for grading each player's physical ability, but must also gather medical and character information. ${ }^{227}$ Such information is crucial in

223. See College Football Teams, ESPN.com (last visited Mar. 10, 2013), http:// espn.go.com/college-football/teams (providing team breakdown of all football college divisions).

224. See Balladeer, 41 NAIA, D2 and D3 College Football Players to the NFL for 2012, BALladeER's Blog (May 4, 2012), http://glitternight.com/2012/05/04/40naia-d2-and-d3-college-football-players-to-the-nfl-for-2012/ (providing list of players recruited from these lower-tier schools to play in NFL).

225. See Floyd Reese, College Scouts Work Tirelessly and Receive Little Public Credit, ESPN.COM (Mar. 8, 2008), (pointing to five specific issues that make job of a college scout difficult). The list includes: the scout's schedule, restrictions placed upon scouts, the debate surrounding whether or not to scout juniors, national scouting, and finally the lack of any public glory. See id.

226. See Who are Blesto $\mathcal{E}^{2}$ the National?, DraftDaddy, (last visited Mar. 10, 2013), http://www.draftdaddy.com/features/blesto.htm (describing process used by two main scouting companies for evaluating draft prospects and providing subscribing teams with such information).

227. See Dr. David Grier, Medical Evaluation of Players Critical at NFL Combine, (Mar. 2, 2011), http://www.drdavidgeier.com/medical-evaluation-of-players-critical-at-nfl-combine/ (explaining lengthy process combine participants must go through for their complete medical evaluation); see also Dr. David Grier, Medical Evaluation of Players Critical at NFL Combine, (Mar. 2, 2011), http://www.drdavid geier.com/medical-evaluation-of-players-critical-at-nfl-combine/ (explaining 
considering a player's draftability. NFL.com writer Pat Kirwan explained that " $[\mathrm{i}] \mathrm{n}$ order to really create long-term change, a GM must fill the roster with good players who also are great men. It doesn't take too many personnel mistakes or bad apples in the locker room to drag a once-proud franchise to the bottom. Smart scouts and great teaching coaches are critical. For example, "[Patriots Head Coach Bill] Belichick does a great job training his scouts to find the type of players he wants, and they rarely bring back guys with character issues or a lack of intellect." 228

Teams nonetheless often gamble that a player's talent will surpass his character concerns. Prior to the 2008 NFL Draft many teams removed former Kansas defensive back Aqib Talib from their draft boards due to concerns over his character. A CBS reporter stated that "[a] GM I trust told me his club was removing Talib's name from its board because of character problems. No one questions Talib has the talent; what they wonder is if he can stay out of trouble." 229 The Tampa Bay Buccaneers believed in Talib and drafted him anyway. Local reports after the Draft posited that Talib's prior troubles "shouldn't be a stop sign. Let's not be naïve here. A lot of college students have tried marijuana. Talib says he has matured, and the Bucs seem ready to believe him."230 Talib has played well, but has also had multiple incidents with the law, leaving his NFL career teetering on the edge. ${ }^{231}$

Even if a player does not have any penchant for criminal activity, it is difficult to know if the player will have the motivation to succeed at the NFL level. As former Rams GM Billy Devaney said in

lengthy process combine participants must go through for their complete medical evaluation).

228. See Pat Kirwan, Here's the 10 Step Program to Creating a Championship Culture, NFL.com, (Jan. 25, 2009), (explaining the importance of 'culture' for football teams, which is described as a "process that takes a vision"). The three main ingredients are: the owner, the tradition, and the quarterback. See id.

229. See Clark Judge, Draft Prospects - Defensive Backs, CBS Sports (April 18, 2008), http://www.cbssports.com/nfl/draft/prospectrankings/DEF/CB; see also [Old article no longer available but text can be found here: http://cowboyszone. com/forums/showthread.php?p=2042224] (noting character was question for many clubs due to Talib's previous off-field behavior).

230. See Gary Shelton, Debates? Talib Has Them Covered, St. Petersburg Times, Apr. 27, 2008, at 1C, (attempting to explain Bucs' reasoning for acquiring Talib despite fact he had tested positive for marijuana three times). His innate talent and skill lead the team to take, what some called, a risk. See id.

231. See Michael David Smith, Aqib Talib Described as All but Gone from Tampa Bay, ProFootballTalk.com (Apr. 24, 2011), http://profootballtalk.nbcsports. com/2011/04/24/aqib-talib-described-as-all-but-gone-from-tampa-bay/ (discussing Talib's problems since joining team, which included fight at rookie symposium, punching teammate in practice, punching cab-driver, and finally assault with deadly weapon charges). 
an interview, "[y] ou want the kid to come in and think this is the first step to being a successful player. Unfortunately a lot of guys bomb out just for that reason, that OK, I'm here, I'm a high drafted player, I've achieved my goals, then they go on cruise control. That's the hard part to figure . . . and you try to spend as much possible time to get a feel for what the kid is going to be like. You have done all the evaluating, the tape study, the combines, the pro days, the all-star games, now you just try to drill down and get as good a feel as you can." 232 All of these issues must be flushed out during the scouting process.

The GM and the College Scouting Director have frequent conversations with scouts as the season winds down. The College Scouting Department will collect the information from the area scouts and the scouting services, in order to narrow the list from around 1,200 prospects to a more manageable 500-600 prospects by the end of the college football season. ${ }^{233}$ The GM and scouting department will then come together following the college and NFL seasons to create a "Black Board" of prospects deemed undraftable based on performance, medical, or character concerns.

The GM and scouting department will also begin ranking players around this time. College all-star games, such as the Senior Bowl take place in January, leading up to the NFL Combine in late February. The NFL Combine, held annually in Indianapolis, is routinely called "the biggest job interview of their lives" for players. ${ }^{234}$ The players undergo extensive examination, including football drills, speed and agility tests, height, weight and size measurements,

232. See PFT Live-Segment 2, ProFootball Talk.com (Aug. 24, 2011), http:// profootballtalk.nbcsports.com/2011/08/24/pft-live-segment-2-billy-devaney/ (explaining how players' personal drive is also important part of scouting process).

233. See Manish Mehta, Inside the New York Jets War Room with GM Mike Tannenbaum and His Inner Circle, DAILY News (Apr. 24, 2011), http://personals.nydaily news.com/blogs/jets/2011/04/inside-the-new-york-jets-draft-war-room-with-gmmike-tannenbaum-his-inner-circle?utm_source=feedburner\&utm_medium=feed\& utm_campaign=feed $\% 3 \mathrm{~A}-\mathrm{ydnrss} \% 2$ Fblogs $\% 2$ Fjets+\% 28Blogs $\%$ 2FThe+Jet + Stream $\% 29$ (providing inside look into Jets' scouting personnel and process).

234. See Rick Alonzo, Decker Playing Catch-Up: Ex-Gopher Hopes Foot Injury Won't Hurt Draft Stock, St. Paul Pioneer Press (Minn.), Feb. 28, 2010, at C3; see also Tom Kowalski, Breaking Through Michigan Players Put Talent on Display, GRAND RAPIDS PRESS, Feb. 28, 2010, at C6 (providing examples of talented players expressing importance of their performance in Combine including their own strengths and weaknesses); Ian R. Rapoport, Combine Notebook: McKenzie, Murphy Talk Things Over, Boston Herald, Mar. 1, 2010, at 66 (noting importance of not burning out too early and over-working themselves); John Vellante, Woburn's McLaughlin Gathers Postseason Honors, Boston Globe, Jan. 21, 2010, at 5 (explaining reason for player's declining invitation to play in Shriners' Football Classic because pre-season workouts were just mere weeks away). 
an intelligence exam, medical exams, and interviews with NFL GMs. ${ }^{235}$

Former Browns and Giants GM Ernie Accorsi once described the evaluation process leading up to the Draft:

We start to get ready for a draft by gathering all of the scouts together - the heroes of the whole process - and talking about every player in the country who's even remotely a prospect. We grade them, both overall and by position, and stagger the names all over the[ ] walls. We'll get together often during the year, finally in a marathon meeting that lasts two or three weeks. By the time April rolls around, every top player has had five, six, seven looks. We start plugging them in by rounds, our own lists of thirty-two. ${ }^{236}$

Scouting players for the NFL Draft is part science, part art, and part pure luck. But, as longtime baseball executive Branch Rickey once said, "luck is the residue of design." Thus, it is clear why NFL GMs must be meticulous in their selection and handling of their college scouting departments.

\section{Professional Scouting}

As discussed above, the NFL Draft is a three-day forum in which each Club essentially showcases the work of its college scouting department that year. Once the final pick of the Draft is entered, all draft eligible players, whether drafted or not, are no longer the responsibility of the college scouting department, but now the professional scouting department. The GM and the Pro Personnel Director are responsible for evaluating all players on the their own roster, all players on other rosters in the NFL, selected players in the United Football League (UFL), the Canadian Foot-

235. See Gregg Rosenthal, Jeff Ireland Apologizes To Dez Bryant, ProFootBallTALK.COM (Apr. 27, 2010), http://profootballtalk.nbcsports.com/2010/04/ 27/jeff-ireland-apologizes-to-dez-bryant/. (explaining it has become common practice in NFL for teams to ask off-beat or even inappropriate questions to test player's ability to handle adversity). Prior to the 2010 NFL Draft, Miami Dolphins General Manager Jeff Ireland asked Oklahoma State wide receiver Dez Bryant if his mother was a prostitute - for which he later apologized. See id; see also Mike Florio, Ken Herock Says No Question Is Off Limits During Pre-Draft Interviews, ProFootBALlTALK.COM (Apr. 29, 2010), http://profootballtalk.nbcsports.com/2010/04/ 29/ken-herock-says-no-question-is-off-limits-during-pre-draft-interviews/ (pointing out skepticism raised as to why these type of pre-employment questions are acceptable in NFL but not in general workforce).

236. See Tom Callahan, The GM, (Broadway Books, The Crown Publishing Group 2008). 
ball League (CFL), the Arena Football League (AFL), and certain players who have played for any of these leagues, but may not currently be employed in professional football.

The GM must of course oversee the scouting department responsible for professional players. The GM and Pro Personnel Director will have current grades on approximately 2,500 potential players. It is the team of professional scouts who develop the necessary reports and grades for review by the GM. Some of these players will be graded out as not adequate and removed from the database, while others will be invited to workout with the Club to get a better assessment of the player.

Professional scouting is important in the world of oft-injured football players. Clubs must constantly be prepared to replace guys with injuries or to replace guys who are underperforming. Almost all Clubs hold workouts every Tuesday where they invite in a handful of free agents at positions about which they are concerned or interested. GMs will keep short lists ready of the guys they are interested in should a spot open up on the roster.

Professional scouting is also crucial prior to and during free agency. GMs and their scouting departments will have had to analyze each player on their roster and project that player's ability to contribute to the Club next season. Where there are gaps, Clubs must be prepared to fill them through the NFL Draft or free agency. If a Club has several talented players at a particular position, it might consider trading a player or releasing the higher priced one.

The professional scouts will grade out every possible free agent shortly after the end of the regular season. ${ }^{237}$ The GM, the coaches and the rest of the staff will then have to determine which players and positions to target. It is not uncommon for Clubs to dust off their college scouting reports to look at a potential free agent's character or medical history. Clubs have limited interactions with players from opposing Clubs and cannot afford to be hesitant once free agency commences.

Not surprisingly, data analysis and video technology are increasingly important tools in scouting departments. New Orleans Saints General Manager Mickey Loomis discussed the Saints' increasing use of technology: "[t]eams are always looking to use tech-

237. See Pat Kirwan, There is No Offseason for NFL Personnel Departments, NFL.com (Nov. 18, 2008), (explaining "[e]very player who competed in 2007 will get a spring film grade to update the team database. That means around 1,700 players should get at least a two-game file grade."). 
nology in a way that makes sense in their organization," Loomis said, "and we're not unique in that regard. But [technological advances] definitely helps us more efficiently process the mountain of information we have on players." 238 With modern technology, offensive, defensive, and special-teams data points all are instantly accessible and can provide detailed play-by-play statistics such as broken and missed tackles, hang time on punts or quarterback pocket location when he threw the ball. ${ }^{239}$ Detroit Lions President Tom Lewand, however, is skeptical of what can be gleaned from an increased focus on statistics and technology: "[t]here are a lot of different ways to look at technical innovations. You're still dealing with substantially the same information. There are just different ways of processing it." 240 Whether an NFL GM is committed to more modern objective data, or instead to more old-fashioned subjective data, the fact remains that he is ultimately responsible for the key scouting decisions that will determine a Club's future.

The result of the scouting process, whether it be the Club's selections in the seven-round of the NFL Draft or in free agency, are among the most important and scrutinized decisions a GM will make. A good addition can help turn around a perennially losing franchise, while bad choices can end a GM's career.

\section{Coach and Personnel Selection}

The GM is generally responsible not only for choosing the players but also the coaches for those players. Considering the importance of the head coach and his concomitant salary, the Club owner and other Club executives may also have a significant say in the selection of a head coach. The head coach and GM will then often work together in putting together a staff of assistant coaches depending on the Club's prior success, some or many of the Club's coaches from the prior year may remain on the staff.

GMs and Clubs have adopted various approaches to their methods for hiring a head coach. Some clubs might hire in-house from their current staff of assistants, as is the case with Cowboys head coach Jason Garrett, Minnesota Vikings head coach Leslie Frazier, and Titans head coach Mike Munchak. GMs either view these

238. See Nancy Gay, Saints Embrace Evaluation Technology, MSN.cOM (Feb. 28, 2011), (pioneering ICE, Interactive Collaboration and Evaluation, Saints arguably have "most streamlined system possible for identifying the best NFL prospects").

239. See id. (admitting in addition to team's increasing use of technology, he is not ready to "give up on the old fashioned draft board either").

240. See id. 
coaches as rising stars they want to hold onto or are more comfortable hiring a head coach with whom they already have a relationship.

When a GM arrives at his position having left a similar role with another organization, he often might look to the coaches with which he used to work in hiring a head coach. For example, when the Browns' head coaching position opened prior to the 2011 season, then Browns and former Eagles GM Tom Heckert looked to a familiar face. Heckert hired Pat Shurmur, who had been a coach with the Eagles from 1999 through 2008, during which time Heckert was an Eagles executive.

If a Club has not produced up to expectations, a GM might look to hire a coach with a distinctly different personality or approach as the departing coach in hopes of shaking things up. For example, when the Giants underperformed with a 4-12 record in 2003, the Giants fired player-friendly head coach Jim Fassel and replaced him with noted disciplinarian Tom Coughlin. Interestingly, it is only after Coughlin admittedly lightened up that he was able to guide the Giants to Super Bowl titles in 2007 and 2011.241

Some GMs prefer to hire veteran coaches with head coaching experience, even if the experience has not always translated to wins. For example, the San Diego Chargers surprisingly hired Norv Turner in 2007. Turner had previously been the head coach of both the Redskins and Raiders but had amassed a 58-82 record during those tenures. Despite some regular season success, Chargers fans have never seemed particularly satisfied with Turner's hiring and he was fired following the 2012 season.

In contrast, it is common for GMs to hire as head coach an offensive or defensive coordinator from a successful Club. For example, the Arizona Cardinals hired Ken Whisenhunt as head coach in 2007, one year after Whisenhunt helped lead the Pittsburgh Steelers to a Super Bowl title as offensive coordinator. In 2012, the Colts hired former Ravens defensive coordinator Chuck Pagano as its head coach. Pagano joined Jets head coach Rex Ryan and Cincinnati Bengals head coach Marvin Lewis as former Ravens' defensive coordinators who rode their success in Baltimore to a head coaching position.

Lastly, some GMs try to make a splash by hiring a successful college coach. The Seahawks hired Pete Carroll in 2010, after Car-

241. See Charean Williams, Giants' Coughlin Lightened Up, Ev Super Bowls Followed, Ft. Worth Star-Telegram (Feb. 3, 2012), http://www.star-telegram.com/ 2012/02/02/3708586/giants-coughlin-lightened-up-and.html (noting Coughlin was given nickname of "Colonel Coughlin" by famous NFL coach Bill Parcells). 
roll had guided the USC Trojans to an 83-19 record over nine seasons. Similarly, in 2011, the 49ers hired Jim Harbaugh after he turned the Stanford Cardinal into a national contender.

A head coach often has control over his assistant coaches, but GMs often insist on retaining longtime assistants or bright young coaches. For example, when Rex Ryan was hired as the Jets' head coach in 2009, the Jets retained 36-year old Brian Schottenheimer as offensive coordinator and 61-year old Mike Westhoff as special teams coordinator. The Jets and then GM Mike Tannebaum viewed Schottenheimer as an up and coming coach in the League while also having a great deal of respect for Westhoff's experience.

Beyond the coaches, the GM is also generally the person responsible for hiring and overseeing all of the members of the football operations staff, including the salary cap personnel, video technicians, trainers and equipment managers. Many GMs, depending on the other titles which they may hold, will also oversee the various other departments that exist in any corporation, such as finance, information technology, and marketing. All of these persons can contribute in some way to the GM's main focus, the Club's success, both on and off the field.

\section{E. Represent the Club}

The GM is the generally the face and voice of the franchise, though certain Club owners, head coaches and quarterbacks demand a certain amount of attention. It is important that a GM have a professional demeanor and strong communication skills for the various roles in which he will be required to represent the Club.

Clearly the most common arena in which a GM must represent the Club is with the media. GMs hold regular press conferences at which they are expected to answer the media's tough questions and to provide the information fans expect and want to hear. Moreover, media might call, text, or email in hopes of gaining access to exclusive information and a breaking story. It is essential that GMs remain cooperative and courteous rather than combative. Good GMs will learn to use the media to their advantage, leaking select bits of information to perhaps curry public favor, gain leverage in a contract negotiation or to put pressure on underperforming players and coaches.

An often overlooked role of a GM is the capacity in which the GM represents the Club in League matters. The NFL has approximately 27 different Committees to analyze and consider important League matters, including the Competition Committee, Finance 
Committee, Stadium Committee, Broadcasting Committee and Management Council Executive Committee. ${ }^{242}$ The Committees, with approximately eight persons each, consist mostly of owners and other Club executives, but GMs are also members of several Committees. For example, the Competition Committee, responsible for changes to the rules, includes Ravens GM Ozzie Newsome and Houston Texans GM Rick Smith. GMs also serve on the Subcommittee on College Relations, the Diversity Committee, and, of course, the General Managers Advisory Committee. ${ }^{243}$

Participation on these Committees not only allows the GM to influence the game and business of football beyond their Club, but also to gain prestige and knowledge.

\section{The Qualifications, Demographics and Career Paths OF NFL GMs}

As discussed above, being an NFL GM is a desirable but difficult position. We can learn more about how people reach this position by examining GMs qualifications, demographics and career paths over the last 20 years.

\section{A. Playing Experience}

\begin{tabular}{|c|c|c|c|c|c|c|}
\hline $\begin{array}{c}\text { PLAYING } \\
\text { EXPERIENCE }\end{array}$ & NFL & $\begin{array}{c}\text { Average } \\
\text { NFL Career }\end{array}$ & College & $\begin{array}{c}\text { Division I } \\
(\text { FBS })\end{array}$ & $\begin{array}{c}\text { Other } \\
\text { College }\end{array}$ & None \\
\hline 1992 & $\begin{array}{c}6 \\
(21.4 \%)\end{array}$ & 7.8 Years & $\begin{array}{c}19 \\
(67.9 \%)\end{array}$ & $\begin{array}{c}11 \\
(39.3 \%)\end{array}$ & $\begin{array}{c}8 \\
(28.6 \%)\end{array}$ & $\begin{array}{c}9 \\
(32.1 \%)\end{array}$ \\
\hline 2002 & 4 & 10.5 Years & $\begin{array}{c}21 \\
(65.6 \%)\end{array}$ & $\begin{array}{c}15 \\
(46.9 \%)\end{array}$ & $\begin{array}{c}7 \\
(21.9 \%)\end{array}$ & $\begin{array}{c}10 \\
(31.3 \%)\end{array}$ \\
\hline 2012 & $\begin{array}{c}7 \\
(21.9 \%)\end{array}$ & 7.9 Years & $\begin{array}{c}24 \\
(75.0 \%)\end{array}$ & $\begin{array}{c}10 \\
(31.3 \%)\end{array}$ & $\begin{array}{c}14 \\
(43.8 \%)\end{array}$ & $\begin{array}{c}8 \\
(25.0 \%)\end{array}$ \\
\hline
\end{tabular}

The playing experience of NFL GMs has not changed dramatically over the years. There is, however, an upward trend of college playing experience, accompanied by an upward trend of GMs whose highest playing level was college other than in the Football Bowl Subdivision (FBS). The most logical explanation for the increase in college experience is that college playing experience is often a prerequisite to obtaining a scouting position with an NFL Club. Scouting, as will be discussed below, is a common path to a GM position.

The increase in GMs from smaller schools, i.e., non-FBS schools, is likely a result of not only the interest in NFL football

242. See NFL Policy Manual for Member Cluubs, Vol. I.

243. See id. 
nationwide, but also the scouting practices of NFL Clubs. Clubs and their scouts are likely aware of almost every small school in the country that has any hope of producing NFL talent. Consequently, players at those smaller schools have increased exposure to get a foot in the door with an NFL Club.

Not surprisingly, the GMs with professional playing experience enjoyed relatively lengthy careers - well more than twice the estimated average NFL career of 3.5 years. ${ }^{244}$ Better, more experienced players are likely to have a better understanding of the business of football and how to construct winning Clubs - not to mention build important relationships to aid their rise to the GM position.

The most prominent former player GMs are the Ravens' Ozzie Newsome (2002-current), who was a Hall of Fame tight end with the Browns, and the Broncos' John Elway (2011-current), a Hall of Fame quarterback who won two Super Bowls with the Broncos.

The most common positions to ascend to the GM position have been quarterback and tight end. The quarterbacks include Elway, Sam Wyche (Buccaneers 1992), Tom Flores (Seahawks 19921994) and Jim Finks (Saints 1986-1993). The tight ends include Newsome, Ken Herock (Falcons 1988-96) and Dwight Clark of "The Catch" (Browns 1998-2002). Quarterbacks becoming GMs is logical as a result of the notoriety quarterbacks have, as well as the perception (borne out by Wonderlic scores) that quarterbacks are often some of the smarter players on the field. ${ }^{245}$

The number of GMs without any playing experience has remained largely constant. These GMs and the paths they took will be discussed in more detail below.

244. See NFL Hopeful FAQs, NFL Players Ass'n, https://www.nflplayers.com/ About-us/FAQs/NFL-Hopeful-FAQs/ ("The average length of an NFL career is about 3 and a half seasons. Although there are some exceptional players who have long careers that extend 10 or twelve seasons and beyond, most players only stay active for about three seasons.").

245. The Wonderlic is an intelligence test prospective NFL players take during the NFL Combine. Quarterbacks have generally scored among the highest. See Greg A. Bedard, Fitting the Profile, Boston Globe, Apr. 24, 2011, at 1, available at 2011 WLNR 7961390 (mentioning that quarterbacks had second-highest Wonderlic scores behind offensive linemen). 
B. Coaching Experience

\begin{tabular}{|c|c|c|c|c|}
\hline $\begin{array}{c}\text { COACHING } \\
\text { EXPERIENCE }\end{array}$ & $\begin{array}{c}\text { NFL Coaching } \\
\text { Experience }\end{array}$ & $\begin{array}{c}\text { Division I-FBS } \\
\text { Coaching Experience }\end{array}$ & $\begin{array}{c}\text { Other College } \\
\text { Coach Experience }\end{array}$ & $\begin{array}{c}\text { No Coaching } \\
\text { Experience }\end{array}$ \\
\hline 1992 & $10(35.7 \%)$ & $9(32.1 \%)$ & $4(14.3 \%)$ & $14(50 \%)$ \\
\hline 2002 & $8(25.0 \%)$ & $12(37.5 \%)$ & $6(18.8 \%)$ & $17(53.1 \%)$ \\
\hline 2012 & $2(6.3 \%)$ & $8(25.0 \%)$ & $10(31.3 \%)$ & $17(53.1 \%)$ \\
\hline
\end{tabular}

Coaching experience, particularly at the NFL level, is not a prerequisite for becoming an NFL GM. In each of the years analyzed, at least half of the GMs had no coaching experience whatsoever. And in 2012, half of those that had coaching experience, had never even coached at the highest collegiate level, let alone the NFL.

Since the advent of professional sports, coaches often doubled as GMs. That still exists today. In 1992, two men served as both head coach and GM: Sam Wyche with the Buccaneers (1992-95); and Tom Flores with the Seahawks (1992-94). There were six GM/ head coaches in 2002: Tom Coughlin in Jacksonville (1995-2002); Andy Reid in Philadelphia (GM effectively from 2001-10); Mike Sherman in Green Bay (2000-05); Bill Belichick in New England (2000-present); Mike Holmgren in Seattle (GM effectively from 1999-2002); and Dan Reeves in Atlanta (1997-2003).

The trend towards the GM/head coach position is captured by legendary NFL coach Bill Parcells' words upon his departure as head coach of the Patriots in 1996. Parcells famously stated: "They want you to cook the dinner; at least they ought to let you shop for some of the groceries. Okay?"246 Parcells comments were believed to be in reference to the Patriots' 1996 Draft. Parcells wanted to draft a defensive player with the Patriots' first-round choice, but was vetoed by Patriots owner Bob Kraft, who instead selected Ohio State wide receiver Terry Glenn. ${ }^{247}$

Many of today's GMs got their start by coaching at small colleges before being hired as a scout at in the NFL. For example, Jerry Reese of the Giants was an assistant coach at his alma mater, the University of Tennessee at Martin, from 1986-93 before being hired by the Giants as a college scout. ${ }^{248}$ Scott Pioli, former GM of

246. Jeff Darlington, NFL Draft is Full of Options at WR for Miami Dolphins, Miami Herald, Apr. 14, 2009, at D5, available at http://content.knowledgeplex. org/ksg/cache/assets/3821/2989/2989448.html(discussing Parcells' opinion regarding head coach ability to also sign players).

247. See id. (noting Parcells' aversion to drafting wide receivers).

248. See Front Office: Jerry Reese, The Official Site of the New York Football GiANTs, http://www.giants.com/team/staff/jerry-reese/a2663861-b927-419b-8c76$601 b 77061319$ (showing biographical information for Giants' GM Jerry Reese). 
the Chiefs, coached for two years at Murray State before being hired by the Browns as a pro personnel assistant. ${ }^{249}$ And, Tom Heckert, former GM of the Browns, spent two seasons coaching at his alma mater, Hillsdale College, before being hired as a scout for the Eagles. ${ }^{250}$

\section{Age}

\begin{tabular}{|c|c|c|c|c|}
\hline AGE & Average Age & 40 and Younger & 60 and Older & $\begin{array}{c}\text { Average Age When } \\
\text { GM For First Time }\end{array}$ \\
\hline 1992 & 53.3 & 2 & 6 & 45.9 \\
\hline 2002 & 52.8 & 1 & 6 & 44.8 \\
\hline 2012 & 50.9 & 2 & 5 & 44.7 \\
\hline
\end{tabular}

Whereas in MLB there has been a trend towards younger GMs, that trend has not noticeably spread to the NFL. ${ }^{251}$ There is almost no statistically significant difference between the number of GMs under 40, over 60, and the age at which GMs become GM for the first time.

The younger GMs over time include John Shaw (40 with the Los Angeles Rams in 1992), Jim Irsay (33 with the Colts in 1992), Ted Sundquist (39 with the Broncos in 2002), Howie Roseman (37 with the Eagles in 2012) and Les Snead (38 with the St. Louis Rams in 2012). Irsay obtained the GM position because his father Robert owned the Club while the other younger GMs all rose through the ranks with one or more NFL Clubs.

The elder GMs include men who were also owners of the Clubs and chose to retain player personnel decision making power. Mike Brown, owner of the Bengals and born in 1935, has controlled the Club since 1991. Al Davis, born in 1929, exercised the same control over his Raiders since he first became GM in 1962 and controlling owner in 1972. Lastly, Jerry Jones, born in 1942, has run the Cowboys since buying the Club in 1989.

249. See Scott Pioli, Mit Sloan Sports Analytics Conference, http://www. sloansportsconference.com/?p=9601 (summarizing Pioli's employment history, achievements, and biographical information).

250. See Tom Heckert General Manager, Official Site of the Cleveland Browns, http://www.clevelandbrowns.com/team/staff/tom-heckert/3b5733a8-02 c4-41d8-ad30-3c1c17543286 (displaying profile of Cleveland Browns' current GM).

251. See Glenn M. Wong \& Chris Deubert, Major League Baseball General Managers: An Analysis of Their Responsibilities, Qualifications and Characteristics, 18 NINE: J. Baseball Hist. \& Culture, 74 (Spring 2010) ("Additionally, the image of a GM has changed over time, as there are younger GMs now than ever before and increasing minority representation."). 
The older GMs that did not own Clubs tend to be football "lifers" with considerable experience. For example, in 1992, 61-year old George Young was in his thirteenth season as the GM of the Giants, having gotten his start in football with the Baltimore Colts in 1968. Ernie Accorsi took over Young's role in 1998, also having gotten his start with the Baltimore Colts in 1970. Accorsi remained with the Giants until retiring in 2007 at the age of 65. The oldest GM in 2012 (besides Mike Brown) was Buddy Nix of the Bills. Nix, aged 72, became the Bills GM in 2009 after a lengthy college coaching career and 16 years as a scout in the NFL. ${ }^{252}$

\section{Education}

\begin{tabular}{|c|c|c|c|c|c|}
\hline EDUCATION & $\begin{array}{c}\text { Bachelor's } \\
\text { Degree }\end{array}$ & $\begin{array}{c}\text { Top 50 } \\
\text { School }^{253}\end{array}$ & $\begin{array}{c}\text { Advanced } \\
\text { Degree }\end{array}$ & J.D. & M.B.A. \\
\hline 1992 & $28(100 \%)$ & $7(25.0 \%)$ & $13(46.4 \%)$ & $3(10.7 \%)$ & $2(7.1 \%)$ \\
\hline 2002 & $32(100 \%)$ & $11(34.8 \%)$ & $16(50.0 \%)$ & $2(6.3 \%)$ & $1(3.1 \%)$ \\
\hline 2012 & $32(100 \%)$ & $2(6.3 \%)$ & $15(46.9 \%)$ & $4(14.3 \%)$ & $0(0.0 \%)$ \\
\hline
\end{tabular}

Remarkably, every NFL GM over the last 20 years has earned his bachelor's degree. In the NBA, there are on average 1.7 GMs each year that do not have a college degree. ${ }^{254}$ In MLB, where many players never attend college, both in 1999 and 2009, six GMs did not have college degrees. ${ }^{255}$

The most remarkable statistic concerning the education of NFL GMs is that 11 of them were from Top 50 undergraduate universities in 2002. The stellar undergraduates included: Rich McKay from Princeton (Buccaneers 1993-2003); Matt Millen from Penn State (Lions 2001-07); Bob Ferguson from the University of Washington (Cardinals 1996-2005); Mike Holmgren from USC (Seahawks 1999-2008); John Butler from the University of Illinois

252. See Buddy Nix, The Official Site of the Buffalo Bills, http:/ www.buffalobills.com/team/roster/Buddy-Nix/8c210bdd-5c03-4698-9e8a-b287b9fcbc72 (displaying biography of Bills' GM from 2010 backward).

253. See National University Rankings, US News \& WORLd Report, http:// colleges.usnews.rankingsandreviews.com/best-colleges/rankings/nationaluniversities (displaying magazine's annual ranking of top U.S. universities).

254. See Glenn M. Wong and Chris Deubert, National Basketball Association General Managers: An Analysis of the Responsibilities, Qualifications and Characteristics, 18 Vill. Sports \& ENT. L.J. 213, 249-50 (2011) (charting NBA GM education and discussing decrease in college players and advanced degrees amongst general managers).

255. See Glenn M. Wong \& Chris Deubert, Major League Baseball General Managers: An Analysis of Their Responsibilities, Qualifications and Characteristics, 18 NiNE: J. Baseball Hist. \& Culture, 74 (Spring 2010) ("While in 1999 and 2009, 24 GMs $(80 \%)$ had a four-year degree.”). 
(Bills 1993-2000, Chargers 2001-2003); Terry Donahue from UCLA (49ers 2001-05); Carl Peterson from UCLA (Chiefs 1989-2008); Bill Polian from NYU (Bills 1986-1993, Panthers 1994-97, and Colts 1997-2009); Ernie Accorsi from Wake Forest (Browns 1985-1992, Giants 1998-2007); Floyd Reese from UCLA (Houston Oilers/Tennessee Titans 1994-2006); and Mike Brown from Dartmouth.

The lawyers in the group include Bears' President from 19832011 Michael McCaskey (Arizona State), Rams' GM from 1983-1997 John Shaw (University of San Diego), Mike Brown (Harvard), Rich McKay (Stetson), Lions GM from 2008-current Martin Mayhew (Georgetown), Eagles GM from 2010-current Howie Roseman (Fordham), and Jets GM from 2006-2012 Mike Tannenbaum (Tulane). None of the current GMs ever practiced law - instead leaving law school and immediately entering the entry levels of the NFL. Mayhew, an eight year NFL veteran, certainly had a leg up.

Those with MBA's over the years include Sam Wyche (South Carolina), Vikings President from 1991-98 Roger Headrick (Columbia), and Headrick's successor with the Vikings until 2004 Gary Woods (Southern Methodist).

\section{E. Professional Experience}

The section below is an overview of GMs' NFL working experience and the previous title they had before they became general managers.

\begin{tabular}{|c|c|c|c|c|}
\hline $\begin{array}{c}\text { PRIOR } \\
\text { EXPERIENCE }\end{array}$ & $\begin{array}{c}\text { Experience } \\
\text { as a Scout }\end{array}$ & $\begin{array}{c}\text { Front Office } \\
\text { Position Other } \\
\text { than GM }\end{array}$ & $\begin{array}{c}\text { Average Years in } \\
\text { NFL Prior to } \\
\text { Becoming GM }\end{array}$ & $\begin{array}{c}\text { GMs Who Were } \\
\text { Previously GMs }\end{array}$ \\
\hline 1992 & $\begin{array}{c}12 \\
(42.9 \%)\end{array}$ & $23(82.1 \%)$ & 12.7 & $2(7.1 \%)$ \\
\hline 2002 & $\begin{array}{c}14 \\
(43.8 \%)\end{array}$ & $23(71.9 \%)$ & 13.3 & $5(15.6 \%)$ \\
\hline 2012 & $\begin{array}{c}21 \\
(65.6 \%)\end{array}$ & $29(90.1 \%)$ & 16.1 & $2(9.4 \%)$ \\
\hline
\end{tabular}

As has been emphasized throughout this article, player evaluation is an NFL GM's top priority. Thus, it is not surprising to see that over the past 20 years more than half of all GMs had some experience at the entry levels of player evaluation - scouting. Then, more than three-quarters of GMs have risen to the GM position through other front office positions, such as Assistant General Manager, Director of Player Personnel or Director of College Scouting. 
Regardless of the path to the position, NFL GMs in recent years have more NFL experience prior to becoming GM, as will be discussed in more detail below.

The persons who avoid the typical path are generally head coaches. As discussed earlier, the following head coaches have held GM or GM-like positions over the years, despite no other front office experience: Sam Wyche (Buccaneers 1992), Tom Flores (Seahawks 1992-94), Tom Coughlin (1995-2002), Andy Reid (Philadelphia Eagles GM effectively from 2001-10), Bill Belichick (New England Patriots 2000-present), Mike Holmgren (Seattle Seahawks GM effectively from 1999-2002), Mike Sherman (Green Bay 200005) and Dan Reeves (Atlanta Falcons 1997-2003).

Others who have avoided working their way through the ranks include Cowboys owner Jerry Jones and prominent ex-players such as John Elway (Broncos 2011-current) and Matt Millen (Lions 200107).

NFL Clubs are seemingly less likely to recycle GMs. Only nine GM positions in 1992, 2002, and 2012 were being held by individuals who had previously served as a GM. In 1992, Chargers GM Bobby Beathard had previously helped lead the Redskins to Super Bowl titles in 1982 and 1987, and Saints GM Jim Finks had previously served a GM of the Bears. In 2002, Texans GM Charley Casserly had previously worked for the Redskins, Bills GM Tom Donahoe had previously worked for the Steelers, Giants GM Ernie Accorsi had previously worked for the Browns, and Chargers GM John Butler helped lead the Bills to another Super Bowl appearance in 1994, after 2002 Colts GM Bill Polian was fired. In 2012, Redskins GM Bruce Allen previously worked for the Buccaneers and Browns GM Tom Heckert previously worked for the Eagles.

In contrast, MLB had nineteen recycled GMs in 1989, 1999, and 2009, and the NBA had seventeen such GMs in the 1988-89, 1998-99, and 2008-09 seasons. ${ }^{256}$ Opportunities for success are clearly fleeting in NFL front offices.

256. See id. (charting GM coaching and front office experience); Glenn M. Wong \& Chris Deubert, National Basketball Association General Managers: An Analysis of the Responsibilities, Qualifications and Characteristics, 18 Vill. Sports \& Ent. L.J. 213,260 ("Over the past twenty year period, GMs have become more experienced, having spent more years in the league prior to becoming a GM."). 


\section{F. Current Experience}

\begin{tabular}{|c|c|c|c|}
\hline $\begin{array}{c}\text { CURRENT } \\
\text { EXPERIENCE }\end{array}$ & $\begin{array}{c}\text { Average Years in } \\
\text { Current Position }\end{array}$ & $\begin{array}{c}\text { Average Years } \\
\text { in the NFL }\end{array}$ & $\begin{array}{c}\text { Average Number of NFL } \\
\text { Teams Worked For }\end{array}$ \\
\hline 1992 & 5.7 & 19.4 & 1.7 \\
\hline 2002 & 5.2 & 19.4 & 2.0 \\
\hline 2012 & 5.7 & 22.2 & 2.4 \\
\hline
\end{tabular}

The subtle trend over time appears to be that NFL GMs have more experience in the NFL. This makes sense. NFL GM positions have become increasingly competitive over the years. Thus, aspiring GMs take the opportunity for a promotion with another Club and often have to wait fifteen or more years before getting the opportunity to become a GM.

Mike Holovak of the Houston Oilers was the most experienced GM in 1992, having amassed 35 years of experience as a player with the Rams and Bears, then as a coach and executive with the Patriots, 49ers, and Oilers. Roger Headrick of the Vikings was the least experienced GM, having joined the Vikings in 1991 as a former business executive with no NFL experience. ${ }^{257}$

The most experienced GM in 2002 was Al Davis, in his 41st year with the Raiders as a coach, executive and owner. Right across the San Francisco Bay, 49ers GM Terry Donahue was in his second season as GM and only fourth season in the NFL after having served as the head coach at UCLA from 1976-1995.

In 2012, Davis, having passed away in 2011, ceded the mantle of most-experienced to fellow longtime owner Mike Brown, who has been with the Bengals in some capacity since his father, Paul, founded the Club in 1968. The least experienced GMs (Howie Roseman of the Eagles and Les Snead of the Rams) still had 12 years of experience in the NFL. Roseman's and Snead's experience reflects that almost universally an NFL GM must work his way through the ranks.

A GM's need to make upward movements from Club to Club can also be demonstrated by the number of GMs who have only worked for one NFL Club. In 1992, 15 (53.6\%) of GMs were still with their first NFL Club. In 2012, only ten GMs (31.3\%) were still with their original Club.

257. See Mike Gelfand, Old Buddy Brooks Didn't Miss Too Much Good Sports News: 1990 Wasn't Greatest Year for Local Heroes on Minnesota's Teams, St. Paul Pioneer Press, Dec. 30, 1990, at 14C, available at 1990 WLNR 2772939; Bob Sansevere, Globe-Trotting Lynn Soon Will Pass the G.M. Torch, St. Paul Pioneer Press, Dec. 30, 1990, at 2C, available at 1990 WLNR 2773392 (chronicling Vikings' GM change). 
The average tenure of an NFL GM is largely unchanged over the last twenty years. The average tenure dropped in 2002 when there were eleven GMs in either their first or second year on the job: Ted Sundquist (Broncos 2002-08); Matt Millen (Lions 200108); Andy Reid (Eagles GM effectively from 2001-10); Mickey Loomis (Saints 2002-current); Jerry Angelo (Bears 2001-11); Charley Casserly (Texans 2002-06); Tom Donahoe (Bills 2001-05); John Butler (Chargers 2001-03); Terry Donahue (49ers 2001-05); Terry Bradway (Jets 2001-06); and Charley Armey (Rams 2001-04).

\section{G. Race and Gender}

\begin{tabular}{|c|c|c|c|c|}
\hline $\begin{array}{c}\text { RACE AND } \\
\text { GENDER }\end{array}$ & Caucasian & African-American & Hispanic & Male \\
\hline 1992 & $27(96.4 \%)$ & 0 & $1(3.6 \%)$ & $28(100 \%)$ \\
\hline 2002 & $31(96.9 \%)$ & $1(3.1 \%)$ & 0 & $32(100 \%)$ \\
\hline 2012 & $26(81.2 \%)$ & $6(18.8 \%)$ & 0 & $32(100 \%)$ \\
\hline
\end{tabular}

Despite the fact that approximately $67 \%$ of NFL players are African-American, NFL Clubs, as in many other sports, have been slow to incorporate minorities into their front offices. ${ }^{258}$ Tom Flores, a Hispanic, was the NFL's only minority GM in 1992 while also coaching the Seahawks. Ten years later, Ozzie Newsome replaced Flores as the lone minority GM in the NFL.

Perhaps even more astonishing than the lack of African-Americans in the front office was the lack of African-Americans serving as head coaches. In 2002, there were only two minority coaches: Tony Dungy with the Colts and Herman Edwards with the Jets. ${ }^{259}$ To address this disparity, in 2003, the NFL, at the insistence of Steelers owner Dan Rooney, enacted what became known as "The Rooney Rule."260 The Rooney Rule requires Clubs to interview at least one

258. See Richard Lapchick, The 2011 Racial E Gender Report Card: National Football League, TiDe SPORT (Sept. 15, 2011), http://www.tidesport.org/RGRC/2011/ RGRC_NFL_2011_FINAL.pdf ("The NFL's score for race decreased slightly from 90.6 in the previous report to 90.4 points out of $100 \ldots 67 \%$ of all players in the NFL are Black.”).

259. See Patrick K. Thornton, The Increased Opportunity for Minorities in the National Football League Coaching Ranks: The Initial Success of the NFL's Rooney Rule, 6 Willamette Sports L.J. 45, 49 (2009) (stating that Edwards was only new African American coach hired since Dungy transferred from Tampa Bay to Indianapolis).

260. See id. at 50; Greg Garber, Thanks to Rooney Rule, Doors Opened, ESPN.com (Feb. 9, 2007, 3:03 PM), http://sports.espn.go.com/nfl/playoffs06/news/story?id $=2750645$ (discussing passing of Rooney Rule, "Teams were required to interview at least one minority candidate when filling a head coaching position-or be fined."). 
minority candidate when looking to fill their head coaching vacancy.

The Rooney Rule has proven successful. Prior to its enactment, there had only been six minority head coaches in the history of the NFL: Flores, Art Shell (Raiders 1989-94, 2006), Dennis Green (Vikings 1992-2001, Cardinals 2004-06), Ray Rhodes (Eagles 199598, Packers 1999), Dungy and Edwards. Since the Rooney Rule's enactment, nine more minorities have become head coaches: Ron Rivera (Panthers 2011-current), Lovie Smith (Bears 2004-12), Marvin Lewis (Bengals 2003-current), Romeo Crennel (Browns 200508, Chiefs 2011-12), Leslie Frazier (Minnesota Vikings 2010-current), Mike Tomlin (Steelers 2007-current), Mike Singletary (49ers 2008-10) Hue Jackson (Raiders 2011) and Raheem Morris (Buccaneers 2009-11).

As a result of The Rooney Rule's success on the field, the NFL extended its application to all searches for senior football operations positions prior to the 2009 season. ${ }^{261}$ Newsome, the lone African-American GM in 2002, was joined the next year by Rod Graves of the Cardinals. Then several NFL Clubs promoted African-Americans to GM positions in the late 2000s: the Texans promoted Rick Smith to GM in 2006; the Giants promoted Jerry Reese to GM in 2007; and the Lions promoted Martin Mayhew to GM in 2008. The sixth African-American GM currently working in the NFL is Reggie McKenzie of the Raiders, hired prior to the 2012 season.

Despite the progress made in racial diversity, the sports world, including the NFL, is still waiting for the first female GM. There are, however, several prominent female executives of NFL Clubs: Amy Trask has been President and CEO of the Raiders since 2005; Dawn Aponte has held several executive positions within the NFL, including at NFL headquarters, with the Browns and with the Dolphins; and Katie Blackburn, the daughter of Bengals owner Mike Brown, is the Club's Executive Vice President. ${ }^{262}$ While both

261. See Tim Smith, The Score: Rooney Rule for GMs Would Be Job Well Done, N.Y. Daily News 71, May 24, 2009, available at 2009 WLNR 9890422 (discussing NFL proposal to expand Rooney Rule in May 2009); Patricia Sheridan, Dan Rooney, Pitt. Post-Gazette, Jul. 18, 2011, at C1, available at 2011 WLNR 14203481 (discussing Rooney Rule's application to GMs in 2011).

262. See Elizabeth Merrill, Raiders' Amy Trask Driven Like Davis, ESPN (Nov. 3, 2011), http://espn.go.com/espnw/more-sports/7181147/oakland-raiders-ceoamy-trask-driven-mentor-al-davis (profiling Trask 14 years into her tenure as Raiders' CEO); see also Dawn Aponte, Mıамi Dolphins (last visited Feb. 14, 2013), http:/ /dolphins.studiotigaapps.net/front-office-bios/football-operations/senior-football-executives/dawn-aponte.aspx (chronicling Aponte's career as Senior Vice President of Football Operations for Miami Dolphins); see also Mark Curnutte, GM 
Aponte and Blackburn have been responsible for negotiating player contracts, no NFL Club has ever turned over its player personnel decisions to a woman.

\section{Common Career Paths}

As demonstrated above, the demographics and experience of NFL GMs have not changed dramatically over time. Consequently, established paths to the GM position have developed while the popularity of newer ones remains to be seen. The career paths below are ordered in terms of their accessibility to the general public, starting with the least accessible.

\section{A. Former NFL Player}

Understandably, several NFL GMs have NFL playing experience. While many former players become coaches, there is a steady population of ex-players that reach the front office. As discussed below, seventeen GM positions during the 1992, 2002 and 2012 seasons were filled by men with NFL playing experience.

The NFL playing experience has assisted these GMs in bypassing a common prerequisite to becoming a GM: scouting experience. As highlighted above, approximately $51 \%$ of GMs in the years examined had scouting experience, including $65.6 \%$ (21 GMs) in 2012. However, only seven of the seventeen (41.2\%) former players also worked as scouts. ${ }^{263}$ In 1992, Ken Herock of the Falcons had previously worked as a scout for Raiders and Buccaneers, and Larry Wilson of the Cardinals rose to GM in 1988 after serving in a scouting capacity for the previous fifteen seasons. ${ }^{264}$ Of the 2002 GMs, Dwight Clark of the Browns got his start by working as a scout for his old team, the 49ers, and Ozzie Newsome of the Ravens also got his start by scouting with his former club, the

Role Proving Full-Time Necessity, Cincinnati EnQuirer, Feb. 4, 2007, at C1 (noting extensive staff required in addition to head coach to run Indianapolis Colts).

263. See Marc Lillibridge, Power Ranking All 32 NFL General Mangers, BLEACHER REPORT (Nov. 16, 2012), http://bleacherreport.com/articles/1411114-power-ranking-all-32-nfl-general-managers (summarizing careers of all thirty-two NFL General Managers of 2012).

264. See Mike Tierney, A Finishing School of Tough Love for Draftees, N.Y. Times (April 24, 2012), http://www.nytimes.com/2012/04/25/sports/football/nfl-finishing-school-emphasizes-herocks-tough-love.html?pagewanted=all (reporting Herock's transition to private draft advisor after 50 years as NFL "player, scout, coach, personnel director, or general manager."); see also Hall of Fame, Arizona CARdinals (last visited Feb. 18, 2013) http://www.azcardinals.com/history/hall-of-fame.html (remarking on Wilson's career with Arizona Cardinals from player to manager from 1960 to 2003 ). 
Browns. ${ }^{265}$ In 2012, Ryan Grigson, GM of the Colts, followed up his one-year NFL career with several years as a scout for the Rams, and Reggie McKenzie of the Raiders started his post-playing career as a scout with the Packers. ${ }^{266}$

The coaching experience of former players has changed dramatically. In 1992, five of the six GMs with NFL playing experience had also coached in the NFL: Sam Wyche was coach/GM of the Buccaneers; Tom Flores was coach/GM of the Seahawks; Falcons GM Ken Herock previously worked as a tight ends coach for the Raiders; Larry Wilson of the Cardinals worked as the Cardinals interim head coach in 1979; and Mike Holovak of the Oilers had previously served as head coach of the Boston Patriots. ${ }^{267}$ In contrast, none of the seven 2012 GMs with NFL playing experience ever coached in the NFL: Martin Mayhew (Detroit 2008-current); Reggie McKenzie (Oakland 2012-current); Ozzie Newsome (Baltimore 2002-current); Ryan Grigson (Indianapolis 2012-current); Bruce Allen (Washington 2009-current); John Elway (Denver 2011-current); and Ted Thompson (Green Bay 2005-present). ${ }^{268}$

The best former players to become GMs are undoubtedly Newsome and Elway. Elway, the Broncos quarterback from 1983-1999,

265. See Jack Thompson, 49ers' Clark Likely Bound for Browns, ChicAgo TribunE (Nov. 29, 1998), http://articles.chicagotribune.com/1998-11-29/sports/98112901 81_1_browns-president-carmen-policy-dwight-clark-cleveland-browns (summarizing Clark's football career at transition from San Francisco to Cleveland); see also Ozzie Newsome, Baltimore Ravens (last visited Feb. 18, 2013), http://www.baltimoreravens.com/team/staff/Ozzie-Newsome/d15bf396-96c8-4050-aead-27a541ac2855 (summarizing Newsome's football career and highlighting successes with Baltimore Ravens).

266. See Ryan Grigson, General Manager, Indianapolis Colts (last visited Feb. 18, 2013), http://www.colts.com/team/staff/Ryan-Grigson/d89d12a6-623d-4ccbae8b-9c3e20720b50 (tracing Grigson's career from NFL rookie, scout, to Colts' GM); see also McKenzie Introduced as General Manager, OKLанома Raiders (Jan. 10, 2012), http://www.raiders.com/news/article-1/McKenzie-Introduced-as-GeneralManager/14bb5161-8b42-4139-917f-9e691bb6768a (reporting Raiders' hiring McKenzie as team's GM and providing career background).

267. See United Press International, Tom Flores Named Seahawks President, General Manager, L.A. Times (Feb. 22, 1989), http://articles.latimes.com/1989-02-22/ sports/sp-393_1_tom-flores (reporting Flores' transition to Seahawks GM after 22year career as player and coach for Raiders); see also Tierney, supra note 264 (summarizing Herock's career); see also Hall of Fame, supra note 264 (summarizing Wilson's career with Cardinals); see also Mike Reiss, Mike Holovak, 88; Star Back for BC Became Second-Winningest Coach of Patriots, Boston Globe, Jan. 28, 2008, http:// www.boston.com/bostonglobe/obituaries/articles/2008/01/28/mike_holovak_88 _star_back_for_bc_became_second_winningest_coach_of_patriots/(remembering Holovak's football career after death in 2008).

268. See Marc Lillibridge, Power Ranking All 32 NFL General Mangers, BlEACHER REPORT (Nov. 16, 2012), http://bleacherreport.com/articles/1411114-power-ranking-all-32-nfl-general-managers (summarizing careers of all thirty-two NFL General Managers of 2012). 
was a nine-time Pro Bowler, won two Super Bowls and was elected to the Hall of Fame in 2004. ${ }^{269}$ Newsome played tight end for the Browns from 1978-90, made three Pro Bowls and was elected into the Hall of Fame in 1999. ${ }^{270}$

Perhaps the most interesting path of a former player belongs to Mayhew. Mayhew, a Florida State graduate, played cornerback for the Redskins and Buccaneers from 1989-96. Following his retirement, Mayhew earned his law degree at Georgetown, graduating in 2000. Mayhew joined the Lions the next year as Senior Director of Football Administration/Staff Counsel. Thereafter, Mayhew moved through the ranks until becoming GM in 2008. ${ }^{271}$

\section{B. Former Coach College Player to Scout}

Perhaps the most common path for NFL GMs is former collegiate player turned scout. Seventeen of the thirty-two 2012 GMs followed this path $(53.1 \%){ }^{272}$ This should not be particularly surprising. While only about 2,000 men are skilled enough and possess the requisite physical characteristics to play in the NFL each year, there are more than 60,000 young men playing college football each year across the three Divisions. ${ }^{273}$ Certainly many of these young men aspire to have careers in football even if their playing careers are limited.

The level of college football played also seems largely irrelevant. Eleven of the seventeen 2012 GMs turned scouts did not play Division I-FBS football. Only three of those eleven even played Division I-FCS football: Jerry Reese of the Giants (University of Tennessee at Martin); Scott Pioli of the Chiefs (Central Connecticut State); and Rick Spielman of the Vikings (Southern Illinois). Four of the GMs even hail from Division III schools: John Schneider of

269. See John Elway, Executive Vice President of Football Operations, Denver BronCOS (last visited Feb. 18, 2013), http://www.denverbroncos.com/team/staff/JohnElway/37e10403-2561-4e20-8e5e-bf841f14cf89 (detailing Elway's career path from player to manager).

270. See Ozzie Newsome, supra note 265 (listing Newsome's career successes).

271. See Martin Mayhew, Detroit Lions (last visited Feb. 14, 2013), http:// www.detroitlions.com/team/staff/martin-mayhew/c907f443-35e8-40fb-a48b-512e 27d1b778 (profiling Mayhew's rise from NFL superstar to Detroit Lions GM).

272. See Marc Lillibridge, Power Ranking All 32 NFL General Mangers, BlEACHER REPORT (Nov. 16, 2012), http://bleacherreport.com/articles/1411114-power-ranking-all-32-nfl-general-managers (summarizing careers of all 32 NFL General Managers of 2012).

273. See NCAA, 1999-2000 - 2009-10 Student Athlete Ethnicity Report (reporting 66,313 men played Division I, II, and III football in 2009-2010), available at http:/ / www.ncaapublications.com/productdownloads/SAEREP11.pdf (compiling statistics on race of collegiate athletics participants). 
the Seahawks (University of St. Thomas); Tom Heckert of the Browns (Hillsdale College); Gene Smith of the Jaguars (Heidelberg University); and A.J. Smith of the Chargers (Kentucky Wesleyan). ${ }^{274}$

Ambitious former college players have clearly been able to turn their advanced knowledge of the game of football into foot-in-thedoor opportunities evaluating talent at the NFL level. Those opportunities are all the more available in light of the fact that NFL Clubs seem not to discriminate against those from smaller schools. From the Club's perspective, it is not a particularly risky venture to take on a former college player, let him perform some scouting services for a year and then reevaluate. Entry level scouts are poorly paid (as low as $\$ 20,000$ ) and finding new and eager persons to take their place in the event they do not work out is simple.

Not surprisingly, the scouting departments of any NFL Club are filled with former college players of varying success looking to climb the ladder. The competition is fierce, but their chosen path is well-traveled.

\section{Salary Cap Expert}

There are of course many people who aspire to become NFL GMs even though they never have and never will possess the physical attributes and skill to become a professional or even collegiate football player, which experience often serves as a prerequisite to a coaching career. These people are not necessarily shut out from achieving their dreams. Instead, these historically must have an astute business acumen, and, in recent years, a mastery of the NFL CBA and Salary Cap.

Entering the 2012 season, there were four GMs who fit this description: Mickey Loomis of the Saints, Marty Hurney of the Panthers, Howie Roseman of the Eagles and Mike Tannenbaum of the Jets.

274. See Jerry Reese, Sr. VP and General Manager, New York GIANTs (last visited Feb. 19, 2013), http://www.giants.com/team/staff/jerry-reese/a2663861-b927-41 9b-8c76-601b77061319 (providing career biography of Reese); see also Scott Pioli, supra note 249; see also Rick Spielman, General Manger, Minnesota Vikings (last visited Feb. 19, 2013), http://www.vikings.com/team/staff/rick-spielman/2616f5fa5818-4289-a4d1-ddb7daf8b07c; see also John Schneider, Seattle Seahawks (last visited Feb. 19, 2013), http://www.seahawks.com/team/staff/John-Schneider/940d 6037-3d45-4898-821f-221e8caa444d; see also Tom Heckert, Cleveland Browns (last visited Feb. 19, 2013), http://www.clevelandbrowns.com/team/staff/tom-heckert/ 3b5733a8-02c4-41d8-ad30-3c1c17543286; see also Gene Smith, Jacksonville Jaguars (last visited Feb. 19, 2013), http://www.jaguars.com/team/scouts/gene-smith. html; see also A.J. Smith, SAn Diego Chargers (last visited Feb. 19, 2013), http:// www.chargers.com/team/staff/a-j-smith/6c7c44d5-f76e-471a-85c8-439dfee97abb (providing which GMs did not play Division I-FBS). 
Hurney's story is perhaps best characterized by good timing. Hurney began his career in sports as a writer covering the Redskins in the 1980 s. $^{275}$ He joined the Redskins public relations department in 1988 and next joined the Chargers in an administrative capacity in 1990.276 When the Salary Cap was implemented in 1993, Hurney emerged as the Club's specialist with the Cap. ${ }^{277}$ Hurney joined the Panthers in 1998 in a similar role. ${ }^{278}$ Finally, in 2002, Hurney ascended to the GM position. ${ }^{279}$ Hurney was fired midway through the 2012 season. ${ }^{280}$

Loomis' career path reflects a reward for diligence in the sports industry. Loomis joined the Seahawks in 1983 within a year after graduating with a master's degree in sports administration. ${ }^{281}$ Loomis had previously earned his accounting degree from the University of Oregon. ${ }^{282}$ Loomis spent 15 years with the Seahawks in a variety of business-focused positions, including Vice President/Finance and Executive Vice President. ${ }^{283}$ Loomis, like Hurney, likely benefited from being with an NFL Club at the time the Salary Cap was first implemented and being forced to assume the responsibility. Loomis joined the Saints in 2000 as the Director of Football Administration, responsible for contract negotiations and Salary Cap management, and was promoted to GM in 2002. ${ }^{284}$

Perhaps the best modern inspirations for the unathletic who nonetheless aspire to become NFL GMs are Tannenbaum and Roseman, who share very similar stories of education, work ethic and sacrifice.

275. See Matt Hurney, Carolina Panthers, (last visited Feb. 17, 2013) http:// www.panthers.com/team/staff/marty-hurney/158dba70-3404-4c01-b1cc-d948ae55 c100 (giving overview of Hurney's career in football)

276. See id. (commenting that Hurney's writings caught attention of Redskins' owner Jack Kent Cooke, leading to job offer with Redskins public relations department).

277. See id. (describing Hurney's emergence with team).

278. See id. (describing Hurney's duties managing salary cap and coordinating with other staff).

279. See id. (explaining GM duties include managing scouting department and coordinating player salaries under Cap).

280. See Pat Yasinkas, Panthers Fire GM Marty Hurney, ESPN (Oct. 22, 2012, 5:07 PM) http://espn.go.com/new-york/nfl/story/_/id/8795617/new-york-jets-firemike-tannenbaum-rex-ryan-keep-job (reporting Panthers' decision to fire Hurney when Panthers record was worst in its conference).

281. See Mickey Loomis, New Orleans Saints, (last visited Feb. 17, 2013) http:/ /www.neworleanssaints.com/team/staff/mickey-loomis/39e8ebc4-2cec-46b2-8d0ca5607c01a6ce (referencing Loomis's master's degree from Wichita State University)

282. See id. (discussing Loomis' educational history).

283. See id. (discussing Loomis' first job in NFL).

284. See id. 
Tannenbaum earned an accounting degree from UMass-Amherst before heading off to Tulane Law School. ${ }^{285}$ While at Tulane, Tannenbaum worked as an intern and player personnel assistant for both the Saints and Browns. ${ }^{286}$ By that time, Tannenbam had made it his goal to become a GM and built an "infrastructure" within and around himself designed solely to reach that goal. ${ }^{287}$ While with the Browns, Tannenbaum had the opportunity to work with then Browns' head coach Bill Belichick. When Belichick was fired after the 1995 season, he returned to being an assistant to his mentor, Bill Parcells, in New England for the 1996 season. Parcells was hired as the Jets head coach prior to the 1997 season, bringing Belichick with him as defensive coordinator. Tannenbaum, having just graduated from Tulane, used his relationship with Belichick to assist in being hired as the Jets' Director of Player Contracts that same season. 288

Tannenbaum added various titles over the next few years, reflecting his education in the game of professional football. For example, in 2000, Tannenbaum added the title "Director of Pro Player Development," indicating increased responsibility for talent evaluation and cultivation. ${ }^{289}$

When Parcells left the Jets after the 2000 season, longtime Chiefs' personnel executive Terry Bradway took over as GM. ${ }^{290}$ Tannenbaum was also then elevated to Assistant GM/Director of Pro Personnel. ${ }^{291}$ Finally, after nine full seasons of tutelage, Tannenbaum was promoted to GM in 2006, taking responsibility for all player personnel decisions. ${ }^{292}$ Tannenbaum was fired following the

285. See Mike Tannenbaum, N.Y. JeTs (last visited Feb. 17, 2013), http://www. newyorkjets.com/ms/media-guide/2012/html/Tannenbaum,-Mike-1.html

286. See id.

287. See Interview with Mike Tannenbaum, former General Manager, New York Jets of the NFL (March 28, 2013).

288. See id. (adding that Tannenbaum served as Director of Player Contracts for three seasons).

289. See id.

290. See Terry Bradway, N.Y. JETs, http://www.newyorkjets.com/ms/mediaguide/2012/html/Bradway,-Terry.html (last visited Feb. 17, 2013), (chronicling Bradway's career with N.Y. Jets).

291. See Mike Tannenbaum, supra note 285 (stating Tannenbaum was promoted to assistant general manager/director of pro personnel in 2001).

292. See id. (adding that Tannenbaum also served as senior vice president, football operations/assistant general manager before promotion to GM). 
2012 season. ${ }^{293}$ In his seven years as GM, the Jets had a 57-55 regular season record and reached two AFC Championship games. ${ }^{294}$

Roseman executed a very similar path of determination and education. While still in high school, Roseman began sending letters to NFL Clubs on a regular (if not constant) basis inquiring about positions. ${ }^{295}$ The letters continued while Roseman earned his undergraduate degree from the University of Florida and his J.D. from Fordham Law School in his hometown of New York City. ${ }^{296}$ Tannenbaum, perhaps seeing some of himself in Roseman, interviewed Roseman for a position in 1999. ${ }^{297}$ The Eagles, impressed with Roseman's tenacity, also interviewed Roseman and eventually hired him as an unpaid intern prior to the 2000 season. ${ }^{298}$

Roseman took full advantage of his internship, finishing each night of work by watching film. ${ }^{299}$ A few months later, Roseman earned himself a full-time position as Salary Cap/Staff Counsel, assisting Eagles' President Joe Banner with research and contract negotiations. $^{300}$ In the following years, Roseman took his football education to the next level by giving unsolicited scouting reports to head coach Andy Reid and Pro Personnel Director Tom Heckert. ${ }^{301}$

Roseman slowly ascended in the Eagles' front office, becoming Director of Football Administration in 2003 and Vice President of

293. See Rich Cimini, Jets Fire GM Mike Tannenbaum, ESPN (Jan. 2, 2013, 12:29 AM), http://espn.go.com/new-york/nfl/story/_/id/8795617/new-york-jets-firemike-tannenbaum-rex-ryan-keep-job (reporting Jets' decision to replace Tannenbaum after disappointment with 6-10 record).

294. See id. (adding that Jets reached playoffs three times under Tannenbaum).

295. See Mike Jensen, Howie Roseman Relentlessly Pursued NFL Dream, PhiladelPHiA InQuirer (July 19, 2010), http://articles.philly.com/2010-07-19/sports/2497 0640_1_howie-roseman-joe-banner-nfl-dream (discussing Jensen's life-long focus on becoming GM of NFL team).

296. See id. (stating Roseman continually sent letters to NFL teams starting in high school).

297. See id. (reporting Tannenbaum as saying he only interviewed Roseman because "I have 20 letters from you, and every time I send you a rejection, you'd send a thank you for the rejection").

298. See id. (stating Roseman persistently called both Joe Banner, President of Eagles, along with his administrative assistants in hopes of Banner returning his calls).

299. See id. (noting watching tape was not part of Roseman's job).

300. See id. (reporting that even at beginning of his career when Roseman was given 'simple' tasks he did extensive research, impressing his employer).

301. See id. (reporting that Roseman's unsolicited scouting reports consisted of approximately 150 college players from 2003 to 2006). 
Football Administration in 2006. ${ }^{302}$ A titanic shift in responsibility occurred in 2008, when Roseman was named Vice President of Player Personnel, taking on responsibility for player personnel decisions as opposed to mere Salary Cap and business-related duties. ${ }^{303}$

Heckert was named Eagles GM in 2006, but final say in football matters still belonged to Reid. Consequently, Heckert left the Eagles to become GM of the Browns in 2010. Heckert's departure created the vacancy for Roseman to fulfill his lifelong dream. Roseman was named GM and is currently responsible for the Eagles football operations, including signing free agents and participating in draft selections.

Roseman's rise to prominence, however, has not necessarily sat well with the football lifers. In his first offseason as GM, Roseman was criticized for allegedly "trying to be too smart for his own good" and trying to "bamboozle people" in seeking a trade partner for longtime Eagles quarterback Donovan McNabb. ${ }^{304}$ Roseman thought the criticism unfortunate and stated that he was still working to develop relationships with other Clubs' GMs. ${ }^{305}$

Whether the paths laid out by Tannenbaum and Roseman will become more common among NFL GMs remains to be seen. The recent terminations of Hurney and Tannenbaum suggest Clubs will steer towards hiring more traditional candidates with considerable scouting and player personnel experience. Nevertheless, the majority of NFL Clubs employ persons with law degrees as their Directors of Football Administration or similar titles responsible for the Salary Cap. These individuals undoubtedly seek to broaden their understanding of the game of football in hopes of one day being elevated to GM. Moreover, there are dozens, if not hundreds, of aspiring GMs in college or law school, who view the trail blazed by Tannenbaum and Roseman as a source of inspiration and hope.

302. See id. (noting Roseman's promotions in 2003 and 2006).

303. See id. (stating that Roseman's promotion to vice president of player personnel attracted much attention primarily because "one of these lawyers was switching over to the scouting side").

304. See Mike Jensen, The New Kid on the Block Takes His Lumps, Philadelphia INQUiRER (July 19, 2010), http://articles.philly.com/2010-07-19/sports/24970855_ 1_mike-tannenbaum-trades-quarterback-market (noting remarks from anonymous GM concerning Roseman).

305. See id. (quoting Roseman as saying "I felt that it's important in the months after I took this job that I reach them out to [general managers]. I tried to develop those relationships. That comes with time."). 


\section{Conclusion}

The role of the NFL GM is complicated, multi-faceted, and about as stressful as any job on earth. Nevertheless, the position is as desired as it is demanding. This article analyzed the duties and characteristics of a GM while providing guidance to prospective GMs.

Generally, at least some college playing experience is a required attribute of future NFL GMs. It is not necessarily the playing experience that is important, but the fact that playing experience often leads to experience in the most important aspect of a GM's duties: player evaluation. Even though there is a path for those not skilled enough to play the game at a high level, they too will have to prove they can evaluate talent and find the players that will help the Club win football games. Bottom line, no skill is as important to NFL GMs as the ability to evaluate talent and make player personnel decisions. 
Jeffrey S. Moorad Sports Law Journal, Vol. 20, Iss. 2 [2013], Art. 5 